THE ROLE OF TRANSITIONAL USES, TEMPORARY INTERVENTIONS \& "EPHEMERALITY" IN POST-INDUSTRIAL WATERFRONT SPACES: LESSONS FOR TORONTO'S PORT LANDS

by

Kathryn J. Hickey

BLA, University of Guelph, 2012

\author{
A Major Research Paper \\ presented to Ryerson University \\ in partial fulfillment of the requirements for the degree of \\ Master of Planning \\ in \\ Urban Development
}

Toronto, Ontario, Canada, 2015

(c) Kathryn J. Hickey 2015 
I hereby declare that I am the sole author of this MRP. This is a true copy of the $\mathrm{MRP}$, including any required final revisions.

I authorize Ryerson University to lend this MRP to other institutions or individuals for the purpose of scholarly research

I further authorize Ryerson University to reproduce this MRP by photocopying or by other means, in total or in part, at the request of other institutions or individuals for the purpose of scholarly research.

I understand that my MRP may be made electronically available to the public. 


\title{
THE ROLE OF TRANSITIONAL USES, TEMPORARY INTERVENTIONS \& "EPHEMERALITY" IN POST-INDUSTRIAL WATERFRONT SPACES: LESSONS FOR TORONTO'S PORT LANDS
}

\author{
(C) Kathryn J. Hickey, 2015 \\ Master of Planning \\ in \\ Urban Development \\ Ryerson University
}

\begin{abstract}
Post-industrial waterfronts are often characterized by a time-gap or a moment of standstill between the collapse of a previous use and the transition to a new and future use. However, conventional planning processes often leave these areas in a curious limbo while they are being prepared or while their futures are being determined. Changing contemporary conditions demand that planners re-evaluate urban planning and development approaches. Transitional uses and temporary interventions must be recognized as legitimate and important aspects of the planning process especially in these ephemeral landscapes as they provide an outlet for innovative and adaptive practices. This paper discusses three case studies. The cities of Melbourne, Amsterdam and Hamburg implemented unique and adaptive projects along their waterfronts as mechanisms to catalyze redevelopment and foster social engagement during indeterminate times. This paper explores these projects and applies the strategies used in each to Toronto's vacant and extensively underutilized Port Lands.
\end{abstract}

Key words: design; ephemeral; transitional use; temporary; post-industrial; waterfront 


\section{Acknowledgements}

First and foremost, I offer my sincerest gratitude to my supervisor, Professor Lister, for her continuous support, and for her patience, motivation, enthusiasm, and guidance during the development and progression of this research paper. I am so deeply grateful for her help, professionalism, and support throughout this project.

I would also like to thank my second reader, Erin Tito for her thoughtful guidance and valuable comments on this research paper.

Finally, I must express my very profound gratitude to my parents for providing me with unfailing support and continuous encouragement throughout my years of study. This accomplishment would not have been possible without their endless love and support. 


\section{Table of Contents}

Abstract.

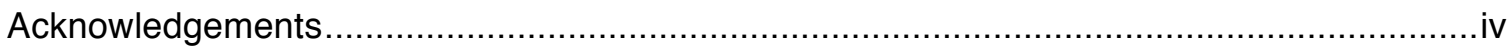

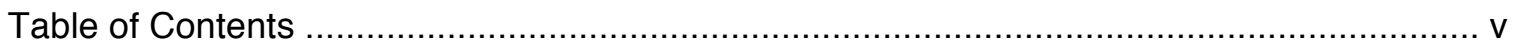

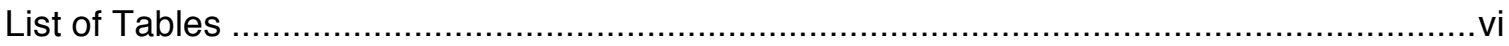

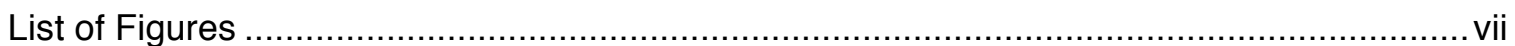

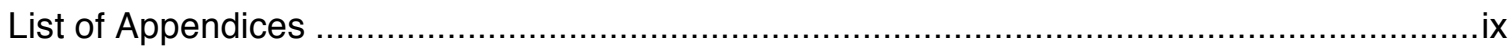

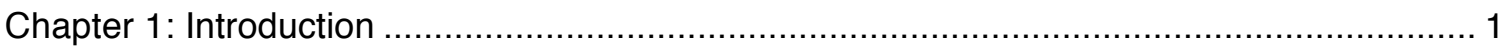

Research Questions and Objectives ............................................................... 3

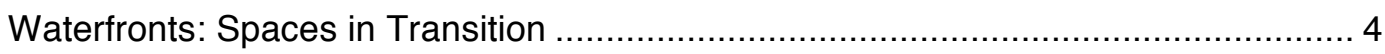

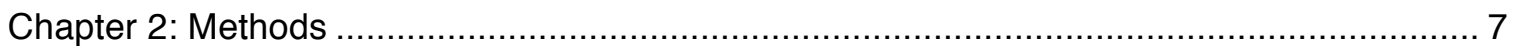

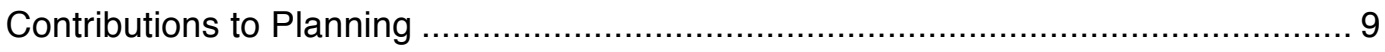

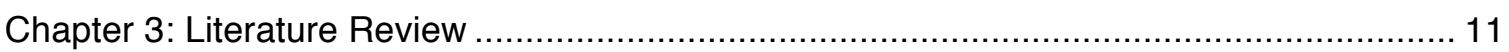

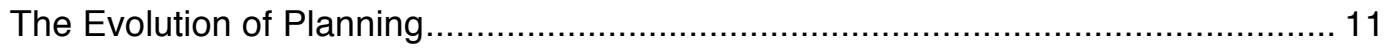

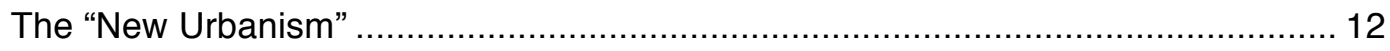

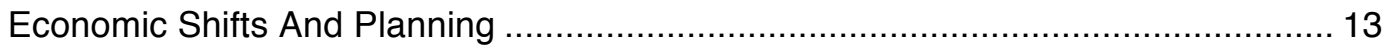

What is a Transitional or Temporary Use? .............................................................. 14

Loose Space, Terrain Vague and the Kinetic City................................................. 16

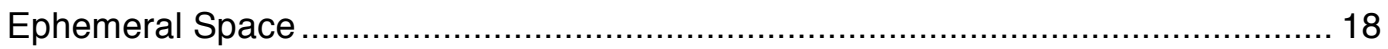

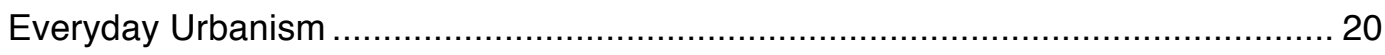

Transitional Uses: Advantages and Disadvantages for Planning.......................... 21

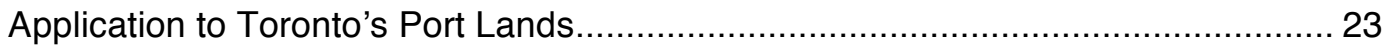

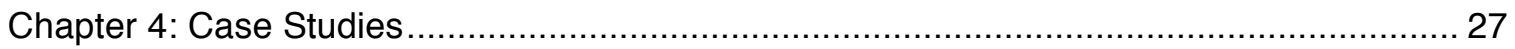

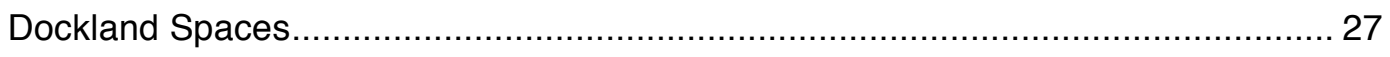

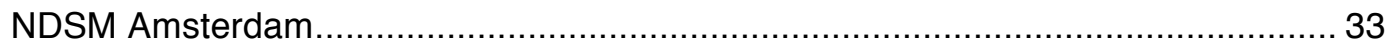

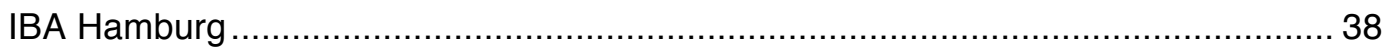

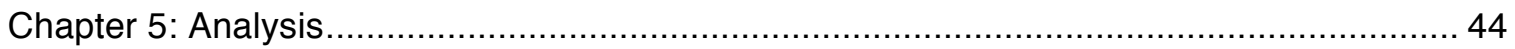

Summary of Key Findings and Recommendations …....................................... 52

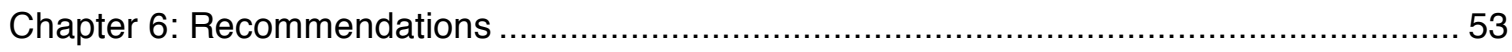

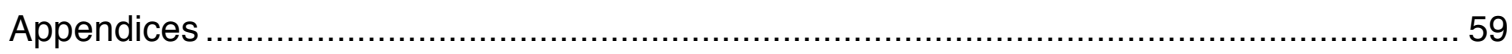

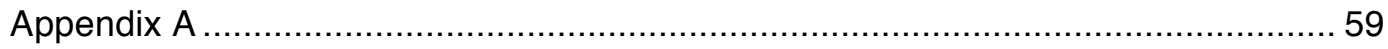

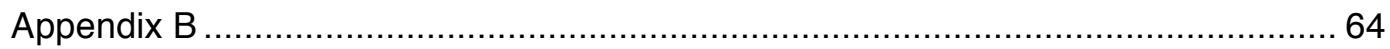

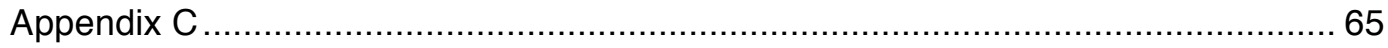

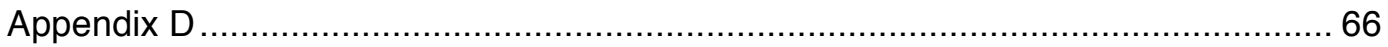

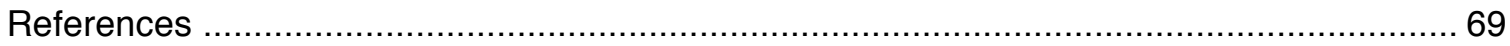


List of Tables

Table 1:

Summary of King Findings and Recommendations 


\section{List of Figures}

Figure 1:

Lynett, Aaron. (2010). A view of the Toronto city skyline, including Toronto's port lands, photographed from an aircraft [Online image]. Retrieved from

http://news.nationalpost.com/2011/08/29/city-wants-take-over-port-lands-developmentpossibly-build-monorail/

Figure 2:

Thompson, Peter J. (2012). A brownfield located in the Portlands just east of downtown Toronto [Online image] Retrieved from http://news.nationalpost.com/2012/09/01/brown-fields/

Figure 3:

BlogTO. (2014). Hearn generating station [Online image]. Retrieved from http://www.blogto.com/city/2012/12/the_photos_of_the_week_december_8-14/

Figure 4:

Best of Toronto. (2014). The luminato festival's big bang bash at an abandoned power station [Online image]. Retrieved from http://www.bestoftoronto.net/2014/06/photos-theluminato-festivals-big-bang-bash-at-an-abandoned-power-station/

Figure 5:

Urban Melbourne. (2013). Fishermen's bend: How to avoid another Docklands [Online image]. Retrieved from https://urban.melbourne/opinion/2014/11/14/fishermans-bend-how-toavoid-another-docklands

Figure 6:

MAB. (2015). Melbourne: Future projects [Online image]. Retrieved from http://www.mab.com.au/residential/future-projects

Figure 7:

The Food Court. (2014). Float: The Food Court, Docklands [Online image]. Retrieved from http://the-food-court.net.au/wpcontent/uploads/2014/09/10669041_716239838450280_8374168911199578080_o.jpg

Figure 8:

The Food Court. (2015). The consequences of success [Online image]. Retrieved from http://the-food-court.net.au/wpcontent/uploads/2015/01/10917156_772592179481712_823136313186510499_o.jpg

Figure 9:

Dockland Spaces (2014). Kelly cube [Online image] Retrieved from http://docklandsspaces.org 
Figure 10:

Dockland Spaces. (2014). What's on @ Dockland Spaces in December [Online image].

Retrieved from http://docklandsspaces.org

Figure 11:

STEALTH Ultd. (2003). Northern IJ bank, former NDSM shipyards [Online image] Retrieved from

http://www.stealth.ultd.net/stealth/03_amsterdamnoord.tmp.html

Figure 12:

EVA Deklerk. (n.d.). "Kunststad": Art City [Online image]. Retrieved from http://www.evadeklerk.com/en/kunststad/

Figure 13:

EVA Deklerk. (n.d.). "Kunststad": Art City [Online image]. Retrieved from http://www.evadeklerk.com/en/kunststad/

Figure 14:

STEALTH Ultd. (2003). Diagram showing change in relations (from 1980 ís till 2003) between alternative (squatting: yellow/orange) and institutional (city: blue) forces in Amsterdam towards unusual coalitions [Online image] Retrieved from

http://www.stealth.ultd.net/stealth/03_amsterdamnoord.tmp.html

Figure 15:

STEALTH Ultd. (2003). Space/Time diagram: 1 - existing use, 2 - planned, 3 - time/space gap, showing the possibilities for alternative programs to enter the redevelopment process [Online image] Retrieved from

http://www.stealth.ultd.net/stealth/03_amsterdamnoord.tmp.html

Figure 16:

The Human City Project. (2013). International building exhibition Hamburg [Online image] Retrieved from https://humancityproject.wordpress.com/2013/10/08/international-buildingexhibition-hamburg/

Figure 17:

IBA Hamburg GmbH. (2014). IBA post 2013 [Online image]. Retrieved from http://www.ibahamburg.de/en/iba-in-english.html

Figure 18:

IBA. (n.d.) Dialogue with citizens [Online image] Retrieved from http://www.ibahamburg.de/en/partcipate/dialoque-with-citizens.html 


\section{List of Appendices}

Appendix A: .....

Case Study Selection Matrix

Appendix B:

..Dockland Spaces Project Criteria

Appendix C:

IBA Excellence Criteria

Appendix D:

IBA Projects by Theme 


\section{Chapter 1: Introduction}

"Globalization of technologies, societies and economies is transforming the world along diverse and unforeseen pathways" (Bowring \& Swaffield, 2013, 96), and the disciplines of planning, urban design, architecture and landscape architecture are confronted by a need to both respect the past and confront the "certainty of uncertain times". The work of Bowring and Swaffield, the Urban Catalyst team, Bishop and Williams (2012), Haydn and Temel (2006) and Franck and Stevens (2006), among others, has sought to highlight the challenge of design in a dynamic landscape, as well as the fundamentality of time and the significance of indeterminacy in a progressively uncertain world. In an age of amplifying unpredictability and instantaneous change, planners, designers and policy-makers must continue to acknowledge the certainty of uncertainty. This recognition requires a re-evaluation of conventional planning paradigms, such as product-oriented and deterministic master planning, which detail illusionary aspirations and a "hoped for future in the face of constant and relentless change" (Bowring \& Swaffield, 2013, 100). As Bishops and Williams explain, "the city is never an end state, but is perpetually evolving" and the evidence is rife that: "the historical layers of cities co-exist in a rich mosaic of contrasting, architectural styles" (Bishop \& Williams, 2012, 19) and this four-dimensional city is the reality. According to Abbott (2005), over the last thirty years many writers have claimed that the world is becoming more complex and society and its future are becoming more unpredictable and uncertain. However, as Abbott (2005) explains, uncertainty is omnipresent and the future has always been complex, indeterminate and unknown. People, groups and organizations live with uncertainty daily - each makes choices without a full knowledge of the facts or an understanding of the possible implications, outcomes and consequences. Planners have come to realize that traditional planning processes do not provide solutions to 'wicked problems' - those with no simple solutions, unknown answers, and multiple elements (Rittel and Webber, 1973) - and have recognized that there is not a homogenous worldview. Planners are more aware of changing conditions, conflicting sources of information, the prevalence of multiple publics, cultures and perspectives in planning issues, and the complex and unpredictable processes embedded within society that inform planning decisions. As a result, planning processes have become less prescriptive, have emphasized participation and communication 
among stakeholders and individuals, and have come to respect the diversity of opinions. For example, collaborative and communicative planning have emerged as two distinct approaches to address complex urban problems; both rely on authentic dialogue, empowerment, the representation of shared interests, joint learning and emancipatory knowledge, consensus-building, interdependence and diversity among players (Innes \& Booher, 2012; Innes, 1996). Therefore, planning processes are becoming more open to uncertainty and planners have come to realize that social and urban problems cannot be solved through purely scientific and rational analysis; doing so fails to confront the pluralistic nature of the city and society. Cities evolve, develop and decay and urban conditions constantly change. Therefore, there is an argument to be made for designing, constructing and planning temporary landscapes for short, medium and interim use with transition built into the outcome.

Some public authorities today remain highly concerned with prediction, order and control and, in doing so, attempt to develop permanent, long-term and long-lasting solutions (Bishop \& Williams, 2012). Most large-scale developments, many of which follow a product-oriented master plan, have a twenty to thirty year preparation, planning and implementation timeline; however, city authorities lack the resources, power, control, as well as the political, social and fiscal capital to implement these formal and allencompassing masterplans (Lyndon, Bartman, Woudstra \& Khawarzad, 2012; Bishop \& Williams, 2012). In consequence, the 'Death of the Master Plan' has become a prominent theme in planning and urbanism. As indicated by Turner, (1996) with master plans, "the totality is too precise [and] the details are not precise enough" (56). Wall (1999) describes that: "the potential and significant field of action today is less the design [...] of master plans than the careful modification and articulation of the urban surface" (247). Corner (1999) argues that urban and regional futures must derive less from a utopia of form and more from a utopia of process that both respects and reflects how things work, interact and inter-relate in space and time. Maps and the layering of planes and structures display a composite field of multiple parts and elements; such richness and complexity cannot be gained by the single master plan or zoning plan (Wall, 1999).

In the absence of certainty and predictability, planners and designers must continue to take a multifocal perspective and consider flexible and adaptive planning, 
design, and management strategies (Lister, 2010, 527). Similarly, there has been little analysis on the importance of transitional uses and temporary interventions in the residual spaces of contemporary cities; these residual spaces, which are partly the result of deterministic planning and design strategies, are left in curious limbo while they are being prepared or while their futures are being determined (Bishop \& Williams, 2012, 14). A further re-evaluation of conventional paradigms and the application of a new breed of urbanism, one that builds on the recognition of uncertainty and "characterized by multiplicity, plurality, diversity and complexity", is both timely and relevant (Lister, 2010, 525). According to Correy (1978), once we accept that permanence is both an unattainable and unnecessary feat is it "possible to think in terms of designing ephemeral environments for transient populations" (Correy, 1978, 102). Planners are increasingly acknowledging the certainty of uncertain times; a re-examination of conventional planning practices in favour of planning alternatives that both celebrate and encourage the uncertain, spontaneous, and momentary aspects of everyday life is necessary. Planners and designers must now consider ephemeral and transitional uses and interim phases of development as increasingly legitimate and powerful tools during these uncertain and indeterminate times as a means for process-oriented incremental change. If planners hope to validate several voices and opinions in the planning process, they must recognize the importance and legitimacy of ephemerality and transitional use. Cities evolve, develop and decay. Therefore, there is an argument to be made for designing, constructing and planning temporary landscapes for short, medium and interim use.

\subsection{Research Question and Objectives}

1. How can we find a meaningful role for transitional and ephemeral uses in the practice of urban planning?

2. How might transitional and ephemeral uses be harnessed as strategic instruments in the processes of urban regeneration and socio-spatial transformation?

3. What role can transitional uses play in the redevelopment of post-industrial waterfronts such as the Port Lands in Toronto? 
The research objectives are:

1. Explore the concepts of 'loose space', 'terrain vague' and ephemeral space and their applicability to the Port Lands;

2. Determine how planners can not only find a role, but also embrace ephemerality in planning and urban design;

3. Examine how temporary uses have been used in other geographic regions to mobilize regeneration and catalyze the development of post-industrial; waterfronts, including the role that they have played in the place-making process

4. Determine applicable lessons for the Port Lands as it seeks development.

\subsection{Waterfronts - Spaces in Transition}

Residual, abandoned and overlooked spaces exist throughout the contemporary landscape. While some of these spaces are no longer economically viable or are resource deplete due to extraction and use, others have never been productively used (Lister, 2006). Waterfronts, for example, have historically been the economic staging point of cities (Marshall, 2001). With the advent of trade and the growth of industrialization, waterfronts were favored as sites for shipping, manufacturing and industrial activity. Long before the rise of road, rail and air travel, people depended on water to connect regions and continents and to move both people and goods. However, the rise of the knowledge-saturated and information-based economy, at the expense of the former manufacturing-based economy, and the globalization of technologies, societies and economies rendered port and waterfront industries obsolete. In many cities around the world, it has taken years, if not decades, to reclaim, remediate and remake these landscapes into productive spaces once again. As a result, waterfronts are often characterized by a time-gap or a moment of standstill, between the collapse of a previous use and the beginning of a future use, and the notion that they will eventually be transformed.

As it is "along its waterfront [that the] aura of a city resides and persists" (Krieger as cited in Marshall, 2001, 7), it is necessary to consider new strategies such as transitional uses, temporary interventions and interim phases of development to reactivate waterfront spaces currently in transition and in this moment of standstill. 
Global waterfronts have become "a terrain of availability" and, although characterized by "void and absence", they offer potential and possibility (Sola-Morales, 1995). While the rediscovery of waterfronts is becoming a welcome global trend, cities and their authorities often lack the resources, control and fiscal capital to redevelop waterfront spaces leaving them in a curious limbo while they are being prepared or while their futures are being determined (Bishop \& Williams, 2012, 14).

The Toronto Port Lands is an example of a post-industrial space in transition. Similar to other cities, its industrial heart was given over to other uses. The Port Lands present a unique and unprecedented development opportunity for the city to advance its status as a dynamic global metropolis, however the site can accept little new construction until properly remediated. Current planning frameworks, which estimate a thirty-year planning and implementation timeline, coupled with a budget shortfall in excess of some $\$ 500$ million (Tito, 2011), have left the Port Lands in a curious and indeterminate state. With fallow time in excess, there is an opportunity to explore ephemeral and transitional uses to better optimize the use of this spatial resource over the next thirty years.

In the practice of agriculture, fallow time is critical to the restoration and subsequent cultivation of land. Although during fallow time lands remain undeveloped, uncultivated or inactive, the lands are not unproductive. Rather, they serve an important

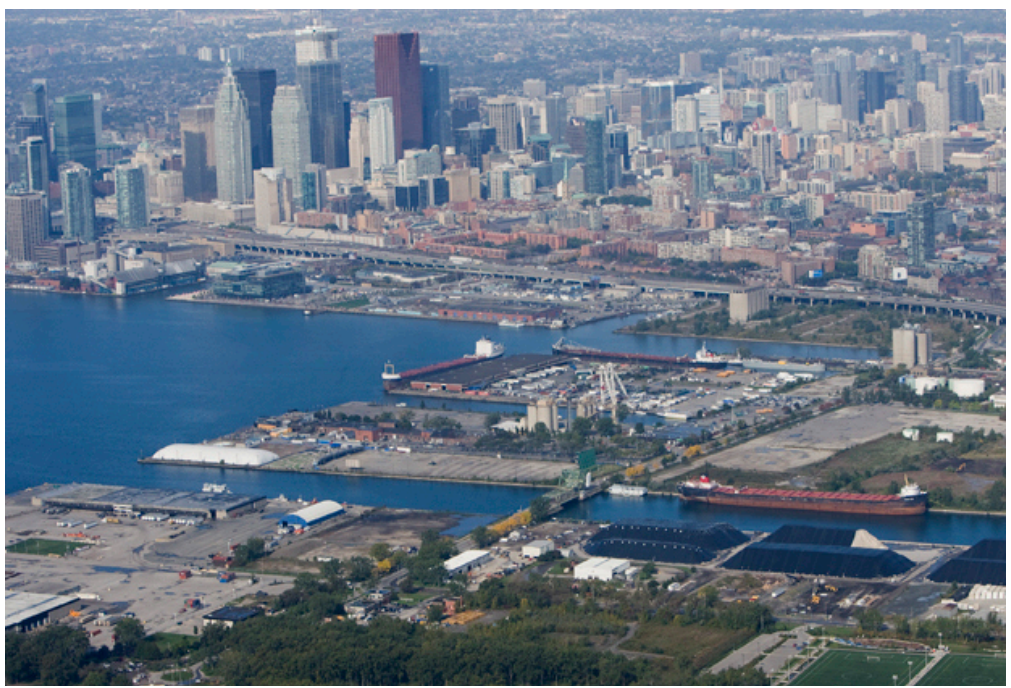

Figure 1: Aerial, Toronto Port Lands 
regenerative and reformative purpose. Therefore, leaving a site fallow while plans develop isn't wasteful; in the case of the Port Lands, fallow time has the capacity to generate potential as well as social and environmental change.

Changing contemporary conditions demand that designers and planners continue to re-evaluate urban planning, development and transformation approaches. For that reason, transitional and ephemeral uses must be considered as an extremely legitimate and important part of the planning process. The Port Lands is a space that is justified for ephemeral uses. Given its indeterminate state, there is an opportunity to encourage transitional uses as a strategic instrument for urban regeneration and physical, social, environmental, and cultural transformation. Transitional and ephemeral uses allow urban residents to create, adapt to, claim and reinvent the urban surface for themselves, and also promise a revitalized role for the design professions (Wall, 1999). Global case studies will illustrate how transitional uses and temporary interventions have been exercised in other cities to mobilize waterfront regeneration, catalyze redevelopment initiatives and promote active stewardship in socially forgotten post-industrial waterfront voids.

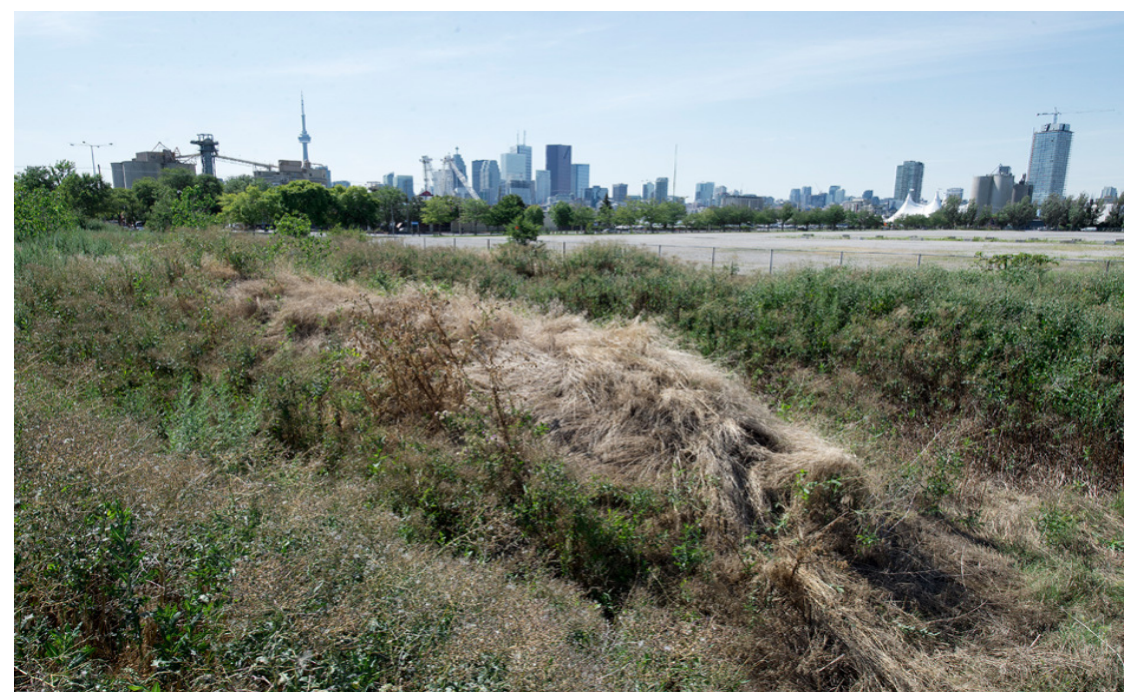

Figure 2: A brownfield in the Port Lands 


\section{Chapter 2: Methods}

The planning and design professions are becoming increasingly aware of the ambiguity associated with the city and its people. This recognition has led to the timely re-evaluation of conventional planning paradigms; as a result, planners and public authorities around the world are beginning to experiment with transitional, temporary and ephemeral uses and process-oriented planning as legitimate and powerful tools for necessary socio-spatial change. The nature of planning as process (process-oriented planning) involves the iterative and progressive transformation of space, through the use of incremental steps and the inclusion of various actors, along multiple socio-spatial dimensions. According to Franck and Stevens (2006), it is necessary to think of planning as "a process that occurs over time [in a series of steps] [...] which might unfold in several directions, where the end result is never defined" (286).

This paper begins with a description of the current academic discourse on the subject of temporary and transitional use, including an examination of the economic, political and social issues that tend to accompany temporary use projects. It will identify the advantages that temporary uses have been shown to provide for a city and its people and will examine the role that specific key agents play in temporary use projects. Social theorists and researches explain that there is a renewed interest in the notion of the 'right to the city'; temporary uses are, therefore, being perceived as an inclusive, bottomup, and participatory approach, contingent on the exercise of a collective power, to reshape the processes of planning, design and urbanization to better reflect the currency of time and validate multiple perspectives. The concepts of loose space, 'terrain vague' and ephemerality are relevant when describing post-industrial landscapes, such as the Toronto Port Lands. Global waterfronts have become "a terrain of availability" and, although often characterized by "void and absence", they offer potential and possibility for innovative planning practices such as temporary uses, which, if tuned accordingly, can carry place-making and development-orientations.

The Port Lands will eventually be developed and although a planning framework does exist, fallow time is in excess; this presents a window where temporary use and ephemerality is appropriate. A series of case studies will be used to demonstrate how 
transitional uses and interventions have been executed in other global cities as a mechanism to initiate the place-making process, mobilize regeneration, catalyze development and provide opportunities for citizen participation. In each of the case studies, transitional plans and ephemeral uses were set in place in parallel with comprehensive masterplans, which demonstrates that temporary uses need not take precedence over long-term plans.

This research uses secondary case studies, planning reports, maps and policy documents as the key sources for analysis. Case studies allow researchers to associate micro-level actions with macro-level circumstances, and observe the details of social processes and cause-effect relations through cross-unit comparison (Neuman, 2011; Berg, 2012). The sources used for analysis are secondary in nature and have therefore been both gathered and interpreted by other researchers. Nevertheless, this research paper will analyze these sources collectively and draw new theoretical and practical conclusions relevant for the planning and design professions and for conceptual application to the Port Lands. For the purposes of this research, three case studies were selected. The selection process solely focused on cities in North America, Australia and Europe; expansion into other geographic regions would have had to consider different social, cultural, political and economic contexts. The cities selected for initial review were evaluated based on the similarities each shared with the Port Lands and Toronto at large (see Appendix A). Beyond political and economic circumstances, comparable characteristics examined include: climate, city size, port size, state of port (contaminated, derelict), port ownership, types and objectives of temporary projects, the role of the municipality, types of citizen engagement, and long-term objectives for the site. Following this initial research process, three cities were selected for more in-depth analysis. Melbourne, Amsterdam and Hamburg each exhibited unique and innovative projects and strategies that were flexible and responsive to changing needs, desires and circumstances. In the cases identified, municipal authorities embraced a looser planning vision and harnessed the power of transitional and ephemeral uses throughout the development of their post-industrial waterfronts. While temporary, transitional and ephemeral uses serve as the unifying theme among case studies, each illustrates a unique strategy taken by municipal authorities to meet the individual objectives relevant 
to their cities and its people. Furthermore, municipal figures themselves play a variety of diverse, proactive and supportive roles in each of the cases.

Collectively, these case studies demonstrate that temporary and ephemeral uses do not have to be incompatible with other methods of planning; instead, they can be used as flexible and permissive tools to complement other long-standing and established methods. In sum, the examination of the Melbourne, Amsterdam and Hamburg cases will examine the role of municipal authorities, citizens and relevant stakeholders, as well as the different transitional and ephemeral uses employed, the evolution or adaptation of spatial and policy frameworks in order to facilitate the projects, and finally the aftereffects of these projects and the associated responses by urban dwellers.

\subsection{Contributions to Planning}

This research has the potential to contribute to the planning, design, architecture and landscape architecture professions. The consequences of globalization and the effects of urbanization demand that designers and planners revise their approaches toward urban development and transformation. Collectively, these disciplines are beginning to challenge conventional planning paradigms and are becoming more cognizant of the fact that there is not a homogenous and all-inclusive worldview. Along with the recognition and acknowledgment of uncertainty, planning and design processes have become less prescriptive with their expectations. According to Wall (1999), a renewed concern with infrastructures, services, mobility, network flows, ambiguous spaces, and polymorphous conditions promises a revitalized role for the design professions. For planners and designers, this involves grafting new instruments and developing new strategies that allow for a transformation of the urban fabric while respecting temporality, efficacy and change. Therefore, transitional and ephemeral uses must be considered as legitimate and important facets of planning. Ephemeral and transitional uses have the capacity to offer a framework for developing flexible uses as needs and desires changes. They can be used as strategies toward targeted physical, social, cultural and ecological transformation. Therefore, this research contributes to an expanding body of knowledge that calls for a re-calibration of our ideas to the currency of our time (Marshall, 2001). It is imperative that planners address issues of temporality, 
ephemerality and change and welcome ephemeral and transitional uses as legitimate instruments in social capital-, community- and city-building. Given that the globalization of technologies, societies and economies is transforming the world along diverse and unforeseen pathways, this research will call on planners to encourage and support the conditions necessary for ephemeral and transitional uses to thrive.

Finally, this research contributes to design-based research methods. While a relatively new silo of academic research, design-based research methods focus on the interaction between visionary concepts, design proposals, design-based dialogue, artistic tools and visual communication, theoretical and empirical evidence and planning policy to develop new concepts, strategies and proposals in urban design (Kiib, 2012). 


\section{Chapter 3: Literature Review}

\subsection{The Evolution of Planning}

For decades, urban planning and its related disciplines have sought to create social order and growth by "organizing and disciplining the unruly and seductive city" (Fabian \& Samson, 2014, 39) through deterministic planning and design. Conventional systems of planning, firmly rooted in the comprehensive-rational planning model, have sought to create a fully rational and predictable world. This era of planning, concerned with developing coherency and efficiency, saw change as a temporary phenomenon where it was "only a matter of acquiring enough information, knowledge and technical skills to construct a world that did not require further change" (Bishop \& Williams, 2012, 21). This involved the creation of hierarchical bureaucracy, rules and regulations and the removal or uncertainties and unknowns through control over nature (Bishop \& Williams, 2012). The use of conventional planning legislation and regulatory systems, and the application of the maxim "form follows function", have had solidifying effects on both urban development and built form and have tended to value product-oriented aspirations. As Bishop and Williams (2012) explain, planning and architecture have acted as "the gatekeeper of land value by allowing development. [Planning and architecture] also inevitably act as a brake on change and experimentation" (14). In the 1960s and 19670s, planning, as noted by Fincher and Iveson (2008), was faulted for its "failure to take [into] account... the diversity of cities and its inhabitants" (2) and the universal model of "the public interest" or "the common good" suggested a commonality and a homogeneity among urban citizens that simply did not exist (Franck and Stevens, 2007). While the commonplace comprehensive-rational planning model has become increasingly discredited, many large-scale, modern day projects continue to replicate the ills of this model (Pagano, 2013). Although an effort has been made to include citizens in planning discourse through participatory planning, many see the process as both frustrating and futile.

While conventional, state-initiated planning is no longer politically, economically or socially viable, "the radical shift to neo-liberal planning policies has failed to offer inclusive models" (Harvey as cited in Studio Urban Catalyst, 2003, 3; Franck and Stevens, 2006, 274). As Stevens (2007) explains, in the pursuit of efficiency and 
productivity, planning has "become the material device apt to organize production [and] control the daily life of producers and the consumption of products" (7). As a result, planning has been said to perpetuate capital growth and socioeconomic polarization (Harvey, 2008).

According to social theorist David Harvey, there is a renewed interest in the idea of the 'right to the city' - an idea first articulated by Henri Lefebvre - that defines the city as, not simply as asset to claim, but a place to access, use, live and shape, as an equal, regardless of citizenship, ethnicity, income, ability, age, or gender (Fincher \& Iveson, 2008). David Harvey describes it as follows:

The right to the city is far more than the individual liberty to access urban resources: it is a right to change ourselves by changing the city. It is, moreover, a common rather than an individual right since this transformation inevitably depends upon the exercise of a collective power to reshape the processes of urbanization. The freedom to make and remake our cities and ourselves is, I want to argue, one of the most precious yet most neglected of our human rights" (Harvey, 2008, 1-2).

The failures of conventional and neo-liberal planning policies underscore the need to consider alternative models of development that better provide citizens with the opportunity to "claim some kind of shaping power over the processes of urbanization" (Harvey, 2008, 1-2).

\subsection{The "New Urbanism"}

Planning academics, researchers and practioners are also increasingly challenging conventional planning and design strategies. For example, Rem Koolhaas has proposed the abandonment of traditional architectural values and the unearthing of hybrid models:

If there is to be a "new urbanism" it will not be based on the twin fantasies of order and omnipotence; it will be the staging of uncertainty; it will no longer be concerned with the arrangement of more or less permanent objects but with the irrigation of territories with potential; it will no longer aim for stable configurations but for the creation of enabling fields that accommodate processes that refuse to be crystallized into definitive form (Koolhaas, 1998, 961). 
Similarly, scholars such as Margaret Crawford, Jan Gehl, Kevin Lynch and Jane Jacobs have contributed to a body of written work that celebrates the contributions of informal, unplanned, spontaneous, repressed, unnoticed, and unconscious activities on the overall richness of public spaces. Therefore, a re-examination of conventional planning practices, in favour of planning alternatives that both celebrate and encourage the uncertain, spontaneous, and momentary aspects of everyday life, seems both timely and relevant.

\subsection{Economic Shifts and Planning}

The rise of the service-oriented, knowledge-based economy, including the progression of technology and the growth of suburbia and 'malleable' employment, coupled with industrial stagnation, weak economic cycles, uneven patterns of development and investment, and the relocation of industrial production have led to the emergence of high vacancy rates and the creation of industrial wastelands (Bishop \& Williams, 2012). These shifts in the contemporary landscape reinforce the 'certainty of uncertain times' and the inevitable unpredictability of the physical, economic and social worlds. However, it is precisely in these uncertain times when "imagination and vision is most needed to initiate strategic changes...[that] enable society to better adapt to the revealed dynamics of landscapes" (Bowring \& Swaffield, 2013, 103) and provide an outlet for strategic innovation.

While some planning strategies have local authorities concentrating their efforts and resources on specific areas within the city and "hoping to notch up exemplary successes, albeit at the expense of a more broadly conceived intervention policy" (Ronneberger, 2006, 52), development strategies must take into consideration "the greater whole and avoid defining any one spatial level as the decisive field of action...a perspective is needed that seeks to transcend the individual territorial levels and hence the boundaries of the district and the city too" (Ronneberger, 2006, 54). Planning and design professionals must acknowledge different socio-spatial levels (e.g., horizontally between community and region) and policy scales (e.g., local national, federal levels) in practice and refuse to be confined by fixed boundaries and power relations. 
The failures of conventional and neo-liberal planning, the economic and demographic shift of cities, the recognition of the 'right to the city' and the materialization of planning discourse on informal and spontaneous activity reaffirm that "change is here to stay, as a permanent condition of human life" (Bishop \& Williams, 201221 ). As a profession that has, more often than not, planned for the long-term, planning must consider transitional uses, temporary interventions and interim phases of development as increasingly legitimate and powerful tools for incremental and adaptive change. The Port Lands will eventually be redeveloped. While a planning framework does exist fallow time is in excess. Given that the city is perpetually evolving, this planning framework must consider flexible and adaptive planning, design, and management strategies that respond to the revealed dynamics of the city and respect the changing values of its residents and users. As precedents will demonstrate, transitional uses and temporary interventions can be exercised to mobilize regeneration, catalyze redevelopment, provide residents with the opportunity to become active participants in the shaping of cities and promote active stewardship in the socially forgotten and economically unproductive post-industrial voids.

\subsection{What is a Transitional or Temporary Use?}

Given that conventional planning paradigms, such as product-oriented design, long-term planning and static models of architecture, are becoming increasingly incoherent in a world characterized by constant and relentless change, citizens and city authorities are beginning to experiment with looser planning visions that better reflect the ambiguity of the city. These looser planning approaches, which follow a flexible, tactical and process-oriented approach, include transitional, temporary, provisional or ephemeral uses and activities in a variety of urban spaces. (Bishop \& Williams, 2012; Nisenbaum, 2008).

Temporary, transitional and ephemeral uses can be difficult to define because in practice, and when viewed from a sufficient distance, "any use is temporary" (Temel, 2006, 60). Rather,

Temporary uses are those that planned from the outset to be impermanent. We understand the idea of temporality to be determined, not as its literal meaning would suggest, by the duration of use: temporary uses are those 
that seek to derive unique qualities from the idea of temporality (Haydn \& Temel, 2006, 17)

In sum, the time-limited element associated with a temporary use is simply a measurement and is generally explicit (Bishop and Williams, 2012). The temporary has its own qualities and "should not be viewed as merely a substitute for the fully adequate" (Temel, 2006, 55). Temporary uses respond to local conditions, demand creativity, respond to changing conditions, can exist with little capital and minimal resources, can be transient or recurrent and can be coopted by multiple actors (Lehtovuori \& Ruoppila, 2012). Nevertheless, temporary uses are adaptive and integrative, and rely on collaborative and iterative learning through the use of scale-appropriate experimentation and community-appropriate design (Lister, 2014).

It is important to note that temporary uses do not emerge accidentally; rather they are deliberate and reflect a sense of creativity and engagement within urban space. For example, temporary uses may be citizen-led, where neighbourhood residents attempt to fill a void left by the government, or they may stem from a community's desire to have a place of their own in the city (Bishop \& Williams, 2012; Nisenbaum, 2008; Pfeifer, 2013). Temporary uses can include the appropriation of a vacant building by a start-up business looking to enter the market, or may be used as a strategic tool for engaged citizen participation to empower local communities. While historically temporary uses have been unplanned, often circumventing official planning processes, recent examples show that temporary uses are becoming strategic components of official planning processes. Planners, instead of following conventional methods of development and planning that see the complete erasure and replacement of residual spaces, are including temporary uses in the processes of urban planning and regeneration, development and management, with each contributing to urban cultural and social policies (Lehtovuori \& Ruoppila, 2012).

Oswalt, Misselwitz and Overmeyer (2007) also explain that temporary uses emerge in the gap between a site's former use and its future use, and in former industrial areas that have experienced change. Furthermore, as the basic requirements for implementation of masterplans, such as "continuity of power, resolve, market certainty, finance and the immediate availability of land" (Bishop \& Williams, 2012, 82) are 
increasingly absent, residual spaces, such as post-industrial waterfronts like the Port Lands, are left vacant and marginalized for years, especially if traditional development patterns fail to absorb these residuals sites due to high investment costs, ground pollution, building contamination or lack of appropriate infrastructure (Oswalt et al., 2007; Studio Urban Catalyst, 2003).

\subsection{Loose Space, Terrain Vague and the "Kinetic City"}

These marginalized spaces, neglected by circumstance, are, however, much more than they appear on the surface and are what Sola-Morales calls the "terrain vague" (Sola-Morales, 1995). As explained by Lister (2006), this term is used to describe the paradox that emerges from the neglected spaces of the contemporary city: "void, absence, yet also promise, the space of the possible, of expectation" (Sola-Morales, $1995,120)$. The relationship between the absence of use and the sense of freedom is essential to understanding the potential of the terrain vague. These sites, which are often ignored, absent of regulation and order, without a definitive use and often described as indeterminate, imprecise, blurred, and uncertain have spatial and programmatic potential specifically because they are without order and therefore provide an opportunity for imagination, engagement and innovation and they "contain the expectations of mobility, vagrant roving, free time, [and] liberty" (Sola-Morales, 1995). However, Sola-Morales warns that architecture, as an instrument of organization and rationalization, can ruin the terrain vagues by "introducing violent transformations, changing estrangement into citizenship, and striving at all costs to dissolve the uncontaminated magic of the obsolete in the realism of efficacy" (Sola-Morales, 1995, 123) by imposing order and limits and approaching these spaces as "problems to be solved through design" (Nisenbaum, 2008). Rather, it is crucial to both respect and encourage qualities such as nonfiniteness and non-definitiveness in the terrain vagues.

Building on this notion, the concepts of loose space and ephemeral space are also worthy of exploration. Post-industrial waterfronts, such as the Port Lands, are spaces in transition and the basic requirements for the implementation of their masterplans are often absent. Conventional systems of planning do no know what to do with these spaces before they are redeveloped and during this fallow time, citizens use these spaces and create their own meanings and values. Therefore, temporary uses can 
also be used to inform future planning that is relevant to citizen-established uses and meanings.

Loose space is a concept discussed by Franck and Stevens (2006), who write that in a loose space, "the previously established uses [of a site] have become detached from the space leaving it open for new uses and meanings" (8). While many spaces posses certain spatial, physical and social possibilities for looseness, it is the people, through their own initiative, who fulfill these possibilities (Franck \& Stevens, 2006, 11). Freedom, similar to the terrain vague, is a necessary precursor of loose space as it exposes the space to unanticipated events, new possibilities and meanings, and the pursuance of new activities by multiple publics (Franck \& Stevens, 2006). Furthermore, loose space, like terrain vagues, is characterized by an "absence or abeyance of...determinacy" (Franck \& Stevens, 2006, 17) and the virtues of loose space arise from the qualities of possibility, freedom, diversity and disorder. The looseness of a space can change over time. For example, changes in regulations and prescribed uses might cause a space to become more or less loose. Spaces may start out tight and become loose over time. Similarly, spaces that were once loose can become more controlled.

Edensor (2006) explains that many contemporary spaces are undiluted and serve a relatively definitive purpose. These purified spaces, which are born out of a "distaste for the mixing of unlike categories" contrast with "weakly classified spaces" (251), such as the loose spaces or terrain vagues of the contemporary city, which possess imprecise boundaries and uncertain futures. These unpurified spaces allow for diversity, greater self-governance and creative expressiveness. Mehrotra (2008) describes the negotiations between what he calls the 'Static' and 'Kinetic' cities. The 'Static City', largely inspired by modernist principles, is a monumental, two-dimension entity built for permanence. The 'Kinetic City' is perceived as a city in motion - temporary in nature and constantly modifying and reinventing itself. Similar to the notion of 'loose space', the virtues of instability and indeterminacy are fundamental to the 'Kinetic City'. Mehrotra (2008) describes that, from time to time, the 'Static City' remakes the 'Kinetic City' in its own image; likewise the 'Kinetic City' forces the 'Static City' to "re-engage itself in present conditions by dissolving its utopian project to fabricate multiple dialogues with its context" (216). Exploration of the kinetic and unpurified city allows us to better 
understand "the blurred lines of contemporary urbanism and the changing roles of people and spaces in urban society" (206-7). Planning must embrace the kinetic city and the realities of contemporary life.

The Port Lands is characterized by a time gap and has been left vacant as a result of traditional development patterns. Similarly, the Port Lands is an example of a loose space: it has become detached from its initial maritime activities and port purposes, it is characterized by an absence of determinacy, and its boundaries have become soft over time. This lack of formality and regulation makes this space available for new forms of practice, new meanings and novel possibilities such as temporary uses. Loose space or the terrain vague can serve as the breeding grounds for innovation (Studio Urban Catalyst, 2003; Oswalt et al., 2007, 2013) where transitional uses are the "locomotives for [a] renewed urban culture" (Hentilä, 2003, 18).

\subsection{Ephemeral Space}

Ephemeral space is a concept discussed by Correy (1978) and later Qviström (2004-2009). Correy (1978) explains that all living things go through a life cycle. Similarly, great cities, which are often described in biological terms, evolve, develop and decay. Therefore, he suggests that there is an argument to be made for designing, constructing and planning temporary landscapes for short, medium and interim use. Similarly to Sola-Morales (1995) and Franck and Stevens (2006), Correy (1978) explains that most cities have their fair share of areas sitting vacant as a wasted resource. Some of these spaces are reserved for future uses, others are waiting for a bureaucratic decision to be made about their futures, and others are stalled by difficult regulatory requirements. A temporary landscape:

May be truly ephemeral - one which, by definition, lives and dies within a very short space of time, or it may be one which is constantly changing and being replaced by something else, but the landscape as such may persist for a long time - the components themselves simply come and go (Correy, 1978, 103).

If, under our current system of planning, we continue to have tracts of land changing their use, and from time to time they remain unoccupied, it makes sense to use the land for a temporary purpose rather than to leave it as a wasted resource (Correy, 1978). 
Qviström's (2004-2009) research has focused on ephemeral landscapes located at the urban-rural divide. Qviström describes these landscapes as "irregular, discontinuous zones of dissonance"(2008, 157). These landscapes are characterized by a utopian future: they are "always about to be transformed, and [are] therefore ignored" (Qviström, 2007, 151). Planners tend to plan for the 'before' and 'after', but rarely for the 'in-between' (Oswalt et al., 2007). The urban-rural divide shares many similarities with post-industrial waterfronts like the Port Lands. These sites are often left in a state of a suspension by the act of future planning and therefore lie fallow until plans are realized.

The notion of 'ephemeral space' can also be applied to post-industrial waterfronts in transition. 'Ephemeral' means short-lived, passing, fleeting, brief, momentary or temporary (Qviström, 2007). Qviström uses the term to describe a landscape in transition and an everyday landscape (Tito, 2011). While landscapes await future development, new uses, appreciations and values evolve yet these human and nonhuman activities are rarely considered and seldom studied nor are the qualities that develop during the process of transformation. Similar to loose space, these ephemeral landscapes are not purely empty but open to be found and defined (Qviström \& Saltzman, 2007) .

Qviström and Saltzman (2006) explain that landscapes are a source of competing interpretations and interests. Every activity and representation will "either question or confirm the dominating ways of seeing and ways of acting within the landscape" (22). These re-negotiations are located, situated and have a place and a time. Therefore, "an everyday perspective, focusing on vernacular activities and day-today changes, is fundamental for an understanding of landscape transformation" (2006, 22). In order to understand the landscapes at the rural-urban divide, it is important to focus on the activities, patterns, perceptions and values that have emerged while development is pending as well as the everyday human and non-human life that has continued to reshape and revalue these landscapes (Qviström \& Saltzman, 2006). This calls for "an enhanced awareness of the impact that planning has while plans are not realized" $(2006,38)$. As Mehrotra (2008) explains, the city and its architecture are not synonymous; meanings are not stable nor are they singular. Rather, spaces get 
consumed, reinterpreted and recycled and their significance will change. While the Port Lands are awaiting future development, new values will evolve. Planning must therefore consider the interaction between planning and the activities, patterns, perceptions and values that both change and evolve.

\section{7 "Everyday Urbanism"}

Crawford (2012) explains that everyday urban space is the arena of modern culture and society. She describes everyday space as the physical domain of everyday public activity that exists between the defined and identified realms. Although difficult to discern these places as public space, they exist physically in the junctures between the private, commercial, institutional and domestic realms. These spaces stand in contrast to the heavily planned, designated and designed spaces that are dictated by built form. Described as trivial and commonplace, 'everyday space' includes streets, front yards, parking lots, flea markets and strip malls being claimed for new uses and meanings. Lefebvre (as cited in Crawford, 212) explains that everyday space is a repository of all kinds of shifting meanings where the spaces themselves are constantly shaped and redefined by the ephemeral activities they accommodate. Lefebvre calls these spaces the 'thirdspace' - they are "neither material space that we experience nor a representation of space. [It] is instead a space of representation, a space bearing the possibility of new meanings, activated through social action and social imagination" (Crawford, 2012, 354). Lefebvre argues that the lived experience is more important than physical form in defining a city. Therefore, in order to design within everyday space, there must be an understanding of the life that takes place there. The city is a human and social product and the processes of planning and design must always include opendialogue and an understanding of the lived experience. Everyday urbanism and social change can only be achieved if there is an understanding of the specific conditions that arise from the lived experiences of different individuals on the ground plane (Crawford, 2012). This inevitably calls for a repositioning of the planner and designer - from making decisions outside of contemporary society to being immersed within it and understanding the multiple, transitory and simultaneous activities that shape and redefine public space. 


\subsection{Transitional Uses: Advantages and Disadvantages for Planning}

Aforementioned contributors (Bishop \& Williams, 2012; Oswalt et al., 2013; Haydn and Temel, 2006; Lehtovuori \& Ruoppila, 2012) have identified several social, cultural, economic, public and private benefits that temporary uses may provide. The public or societal benefits are four-folded. For one, temporary uses are a good tool in place-making and support participatory approaches; they support innovative activity by providing affordable spaces for creative enterprises and develop collaborative practices.

Similar to place-making benefits, temporary uses can have a desirable effect on the attractiveness of a location and on surrounding real estate values. Temporary uses can also provide property owners with rental income from otherwise vacant properties.

Temporary uses permit an experiment-driven, trial-and-error approach and therefore yield both quick and tangible results (Pagano, 2013). Temporary uses also allow planners to implement their ideas on the ground, observe the effects, and learn from the results before committing the time and resources to complete long-term development projects (Temel. 2006; Finn, 2014; Oswalt et al. 2007).

Temporary uses can be a strategic resource and an alternative method to capitaloriented development particularly when conventional planning tools are inadequate or ineffective as temporary uses can have considerable effects with minor costs (Studio Urban Catalyst, 2003; Oswalt et al., 2013; Lehtovuori \& Ruoppila, 2012). Finally, temporary uses can be used to inform future planning decisions and when tuned accordingly, can carry a development-orientation. For example, temporary activities can provide "a vehicle for local consultation and [can] help to build a bridge between developer and community" (Lehtovuori \& Ruoppila, 2012, 35). Furthermore, temporary uses can play a strategic role in urban development and can be used as a tool to catalyze redevelopment and community renewal (Bishop \& Williams, 2012). In sum, temporary uses can have wide-reaching effects well beyond the micro-level and have a "field of opportunities" considerably larger than those granted by regular or long-term uses (Fernando, 2006).

However, temporary uses are not without specific challenges. When citizens have invested considerable amounts of time and resources to a temporary use project, 
or if a temporary use has received strong social acceptance, people may react negatively when the temporary uses are replaced or come to an end. For planners, it is difficult to plan for temporary uses knowing full well that they are impermanent.

A common finding across much of the literature suggests that temporary uses are becoming central and strategic components of urban planning and residual spaces characterized as 'loose' have the potential to serve as creative laboratories for the city to experiment with temporary uses, if they are allowed to do so (Bishop \& Williams, 2012; Franck \& Stevens, 2006; Oswalt et al., 2013).

Oswalt et.al $(2006$; 2013) note that, in many cases, temporary uses need the support of key agents, such as municipal figures, who have access to resources or have relevant experiences and practical skills. These agents can "set up a basic legal and organized framework that provide rudimentary infrastructures, which eases the access to vacant locations, and the start of temporary activities for other user groups (Studio Urban Catalyst, 2003, 13). In brief, the input of key agents is most crucial at in the earliest phases a temporary use when "a support network or internal organizational structure needs to be constructed" (Oswalt et al., 2007, 278). Similarly, Bishop and Williams (2012) claim that public authorities should assist indirectly in the implementation of temporary uses and should avoid heavy intervention. Public authorities should not have a steering role but should focus on conditions, including keeping rents low, guaranteeing accessibility, commissioning stakeholders, facilitating partnerships and providing guidance that support and encourage temporary uses. Public authorities should tolerate spontaneity and, where appropriate, create zones of tolerance that leave areas loosely defined to encourage temporary use (Bishop and Williams, 2012). Finally, authorities need to be creative when considering planning regulations and policies since temporary uses often exist in a legal gray area (Arlt, 2006).

Arlt (2006) likens temporary use planning to tactical planning. Unlike strategic planning, which attempts to bring order to chaos through the execution of plans that emerge from "the planning desk [by a person that] works from a position of power (Haydn \& Temel, 2006, 16), tactical planning is dependent on time and is characterized by a lack of power and definitive control. The planner, as a tactician, must instead look to 
exploit opportunities in order to achieve large effects with limited means (Arlt, 2006). Therefore, planners must forge partnerships at the micro-level, integrate strong and weak actors in temporary uses, react ad hoc and proactively to changing conditions, and support small-scale activities.

Temporary uses do not have to be incompatible with other methods of planning but can instead be used as a proactive and permissive tool to complement them. Temporary uses do not have to be completely spontaneous, unplanned, unregulated or ad hoc in nature. Rather, temporary uses can be successfully incorporated into the planning and management of cities and can have long-term effects (Oswalt et al., 2007; Studio Urban Catalyst, 2003). When implemented in residual spaces, temporary uses have the capacity to spur economic activity, enhance social capital, reactivate the space with minimal expenditure, create a market profile, and hasten investment and permanent development.

\subsection{Application to the Port Lands}

The Port Lands have been left in a state of suspension by the act of future planning; long-term plans have been developed for the area however due to financial and environmental challenges, it is taking a long time to see tangible results. During 'inbetween' times, opportunities for innovation and non-conventional thinking emerge. The previously established uses of the Port Lands have become detached leaving it open for new uses and meanings. A successful, healthy city is one that is able to reimagine and reinvent itself many times over as conditions change (Hume, 2014). Planners, acknowledging that uncertainty exists, must now consider transitional uses as increasingly legitimate and powerful tools to reactivate the Port Lands.

The Port Lands are a post-industrial neighbourhood located east of the downtown core in Toronto, Ontario. At approximately 880 acres, the Port Lards cover relatively the same surface area as downtown Toronto (City Planning, 2013). The Port Lands were created in the late 1800's and early 1900's in order to serve the City's growing industrial sector and from the late 1800's until the mid 1900's, the area served as the industrial and economic staging point of the city. However, the shift away from the industrial-based economy to the knowledge-based economy following the Second World 
War rendered the port obsolete. While still used for light industrial and port purposes today, the Port Lands have become a rather neglected lakeside precinct. Similarly, the area hosts an extremely unpleasant pedestrian environment due to its lack of relevant infrastructure and public space.

While a large body of work produced on the Port Lands already exists, Waterfront Toronto (a body which includes all three orders of government), the Toronto and Region Conservation Authority and the City of Toronto have been examining the potential challenges, opportunities and issues associated with development in the Port Lands. Identified challenges include environmental contamination, risk of flooding, and lack of utilities, water, and wastewater infrastructure (Waterfront Toronto, 2012). According to recent documents, the development of the Port Lands involves the completion of areawide flood protection, site-by-site mitigation, soil remediation, the provision of substantial major and local infrastructure, and finally corresponding development. The total investment costs, an estimated $\$ 1.9$ billion, are both substantial and onerous. Given the fact that development will extend over a long period of time and in a large area with complex development programs, which "involve numerous data, analytical and technical assumptions and substantial [...] unknown risks", it is difficult to accurately predict how development will actually unfold (Waterfront Toronto, 2012, 20). Furthermore, a viable business plan (a scenario closing the gap between costs and revenues) is yet to be solidified. Even with many uncertain caveats affecting its development, the Port Lands is still recognized as an unparalleled redevelopment opportunity. The City's Official Plan, the Central Waterfront Secondary Plan and the forthcoming Port Lands Planning Framework are the guiding documents for the development of the area. However, the $\$ 1.9$ billion dollar investment needed to redevelop 880 acres puts the development process at some thirty years. As a result, there is an opportunity to explore and exploit the lands and buildings with temporary uses. The myriad conditions of uncertainty described above make a sound case for the encouragement of ephemerality and the implementation of transitional uses in the Port Lands. Given these variables, it is clear that the development process will be lengthy; transitional uses can serve as an effective way to fill this urban void while encouraging a greater pedestrian presence. 
Given the amount of empty and underused space in the Port Lands, along with the drastic increase in land values and the growing-demand for public space, the idea of implementing transitional uses "makes too much sense to ignore" (Hume, 2014). According to Hume (2014), temporary uses call attention to the forgotten, invisible and overlooked spaces within the city and illustrate their potential. They serve as "spatial resources for doing things differently outside the ordinary, regulated space of the city...[they] are potential sites for a wide range of social activities which differ from those usually afforded preferential status in the city" (Edensor, 2006, 234-41) where temporary uses provide "alternatives to impotence, lethargy and waiting for better times" (Oswalt et al. 2006, 282).

Currently, the potential for regeneration and reanimation of the Port Lands exists. For example, in 2014, Luminato, a Toronto Festival of Arts and Creativity, arranged to have its opening gala, with over 1000 guests, at the Hearn Generating Station in the Port Lands. This event, proving to be a huge success, demonstrated the unlimited potential, appeal and ambition evolving in the Port Lands. Furthermore, the redevelopment of the West Donlands, as well as the use of the area for cultural events and recreational purposes, suggest that there is a resident population to draw from for innovative temporary uses. Currently, however, the space has been left in a state of suspension by the act of future planning. The ongoing planning initiatives in the Port Lands indicate that the area will eventually be developed.

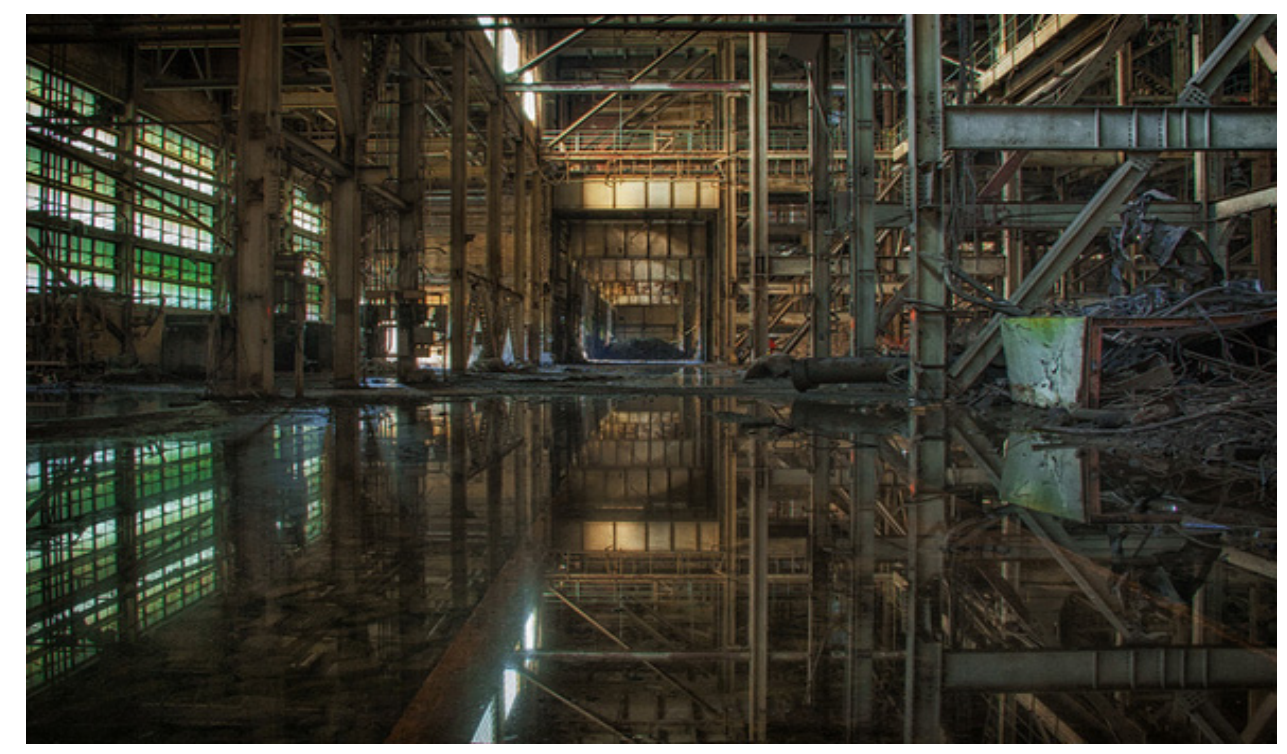

Figure 3: The Hearn Generating Station 
Given the uncertain circumstances affecting its development, as well as the $\$ 1.9$ billion dollar investment needed to remediate and redevelop the area, places the development process at some thirty years. During this time, transitional uses can serve as an effective way to fill this urban void. It is during times like these where strategic change is needed most. In the loosened space of the Port Lands opportunities are rife to explore place-making and development-oriented temporary uses.

Planners and design professionals are becoming more conscious of the lack of homogeneity in the world today. As a result, planning and design processes have become less prescriptive, open to a diversity of perspectives and more reflective of uncertainty. If planners hope to validate several voices through an inclusive and progressive planning process, they must recognize the importance of ephemeral and transitional uses. Given that planning decisions and policies are made in the face of uncertainty, the conditions of ephemerality, experimentation, and temporality must be understood and embraced. The thirty-year development process has opened a window for ephemerality and designed experimentation in the Port Lands.

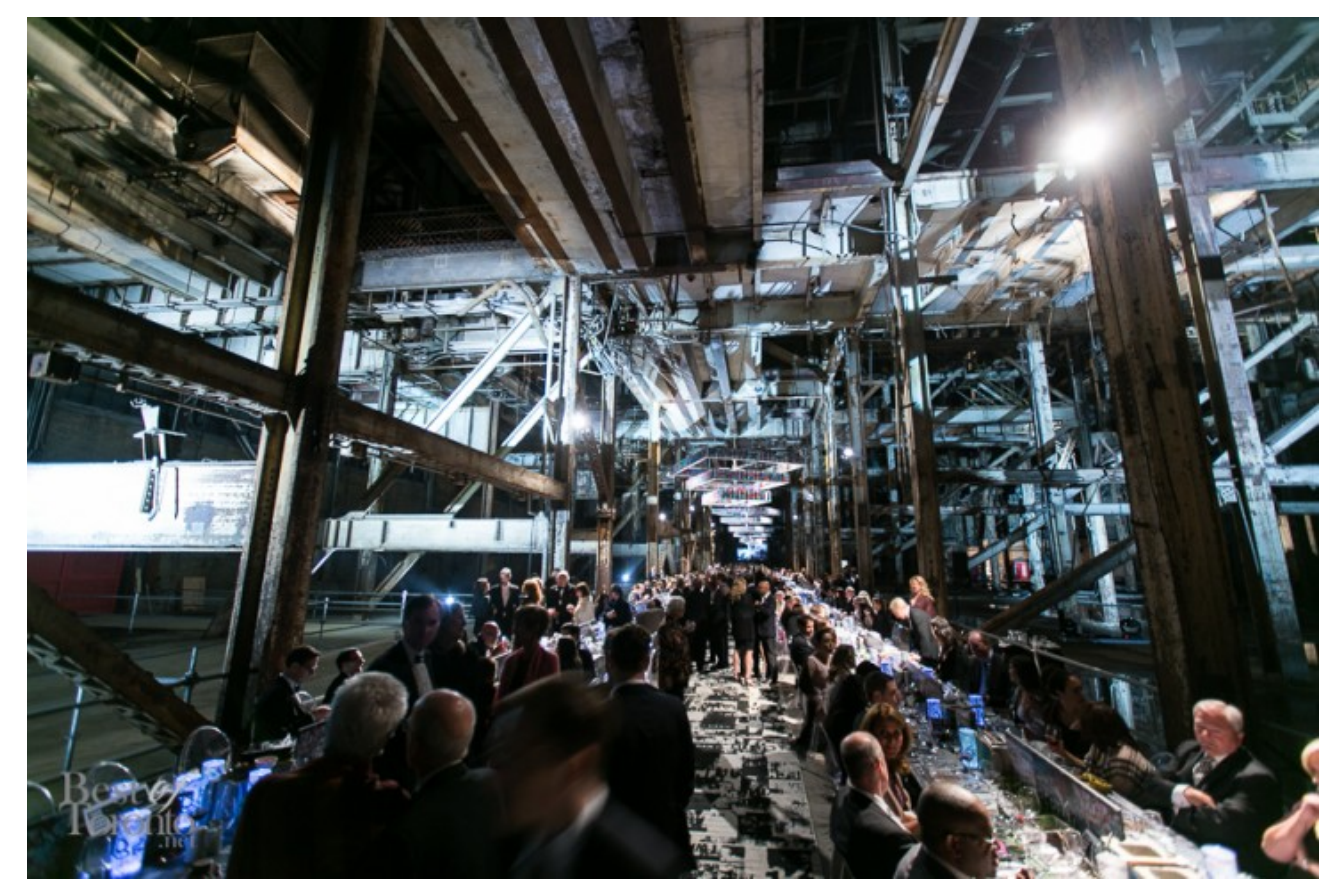

Figure 4: The Luminato Festival at the Hearn Generating Station 


\section{Chapter 4: Case Studies - Planning for Temporary Activity}

\section{Dockland Spaces}

This case study will explore the Dockland Spaces program initiated by the City of Melbourne, Places Victoria and Renew Australia, which has sought to catalyze community renewal and commercial development within the Melbourne Docklands.

The Docklands is a 146-hectare suburb located west of the Melbourne city centre. From the early 1900's to the late 1950's, the area (then called the Victoria Dock) was dominated by industrial and port related activity. Like other post-industrial cities, the effects of containerization, globalization and macro-economic shifts deemed the port irrelevant to the city's needs (Places Victoria, 2015b).

The reclamation of the Docklands began in 1991, following the release of the 'Melbourne's Docklands: A Strategic Planning Framework' by the government of Victoria and the Ministry for Planning and Environment in 1989, with the establishment of the Docklands Authority (who would eventually be replaced by Places Victoria). The Docklands Authority was tasked to oversee the transformation of the Docklands. Once complete, with the anticipated date being the mid to late 2020's, the space will be home to some 20,000 residents and 60,000 workers, in a mix of commercial, cultural, retail and recreational uses (Places Victoria, 2015c).

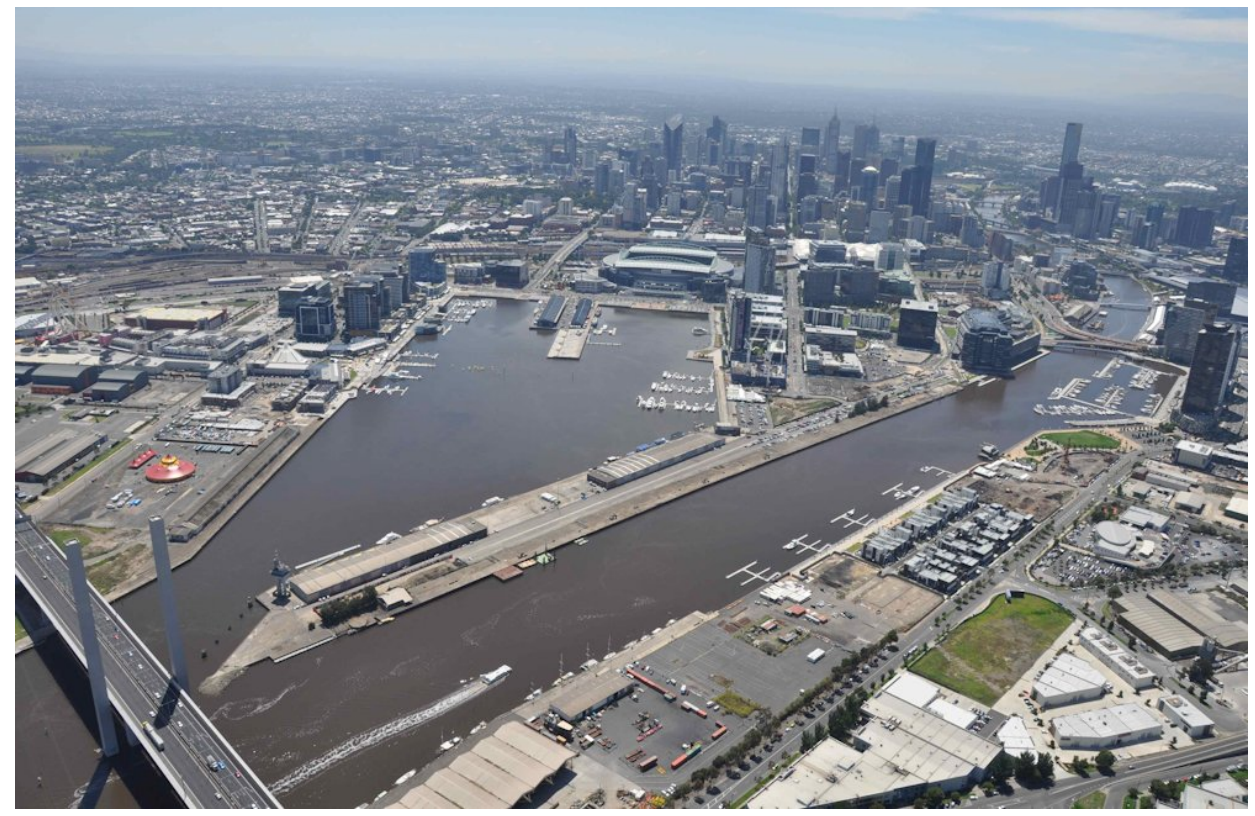

Figure 5: The Melbourne Docklands (pre-development) 
The development of the Docklands was seen as an opportunity for Melbourne to become a world-class city and to both stimulate economic growth and attract national and international investment. From 2000 to 2010, development encouraged involvement by private enterprise through the use of public-private partnerships. In this manner, all design and funding of infrastructure was to be assumed by developers and development was to be delivered in an accelerated manner (Esfahani, 2013). A series of seven (now ten) precincts were established and, at the time of sale, the developer and the Docklands Authority would enter into a binding agreement detailing when and how the precinct would be developed (Places Victoria, 2015a; Esfahani, 2013). However, this approach was criticized for its lack of community involvement. Development, it was argued, did not respect the human-scale nor did it celebrate the potential of the waterfront as a recreational space. The Docklands were underperforming as a public space as a result of its difficult pedestrian environment, the absence of pedestrianappropriate architecture, poor access, and the lack of user diversity (Dockland News, 2014). Given such inadequate results, the development process was re-evaluated; public life in the Docklands needed to be supported by a greater mix of uses, inviting pedestrian architecture, the activation of building edges and the allowance of temporary uses for the community (Dockland News, 2014). Therefore, while the first decade of development was focused on the stimulation of private sector investment and the delivery of infrastructure, the second decade (running from 2010 on) would focus on people, participation, collaboration, community-engagement and partnerships; this attention to the public can be seen in development plans such as the 'Docklands Community and Place Plan' and the ‘Docklands Public Realm Plan’ (Esfahani, 2013).

NewQuay was among the first of the precincts to be pursued for redevelopment. Nevertheless, several shops and storefronts within the precinct are otherwise unoccupied. As an attempt to generate activity, the City of Melbourne, the MAB Corporation (the lead developer in the NewQuay precinct), and Places Victoria commissioned Renew Australia, a not-for-profit company established in 2008, to implement and manage the Dockland Spaces Pilot Initiative. The aim has been to find artists, cultural projects and community groups to use and maintain unoccupied buildings until they become commercially viable or are redeveloped and to spur community renewal, economic development and creative industry. The program takes otherwise 
unoccupied spaces and makes them available to incubate short-term uses by creative enterprises and community initiatives on a rent-free basis (Dockland Spaces, 2012).

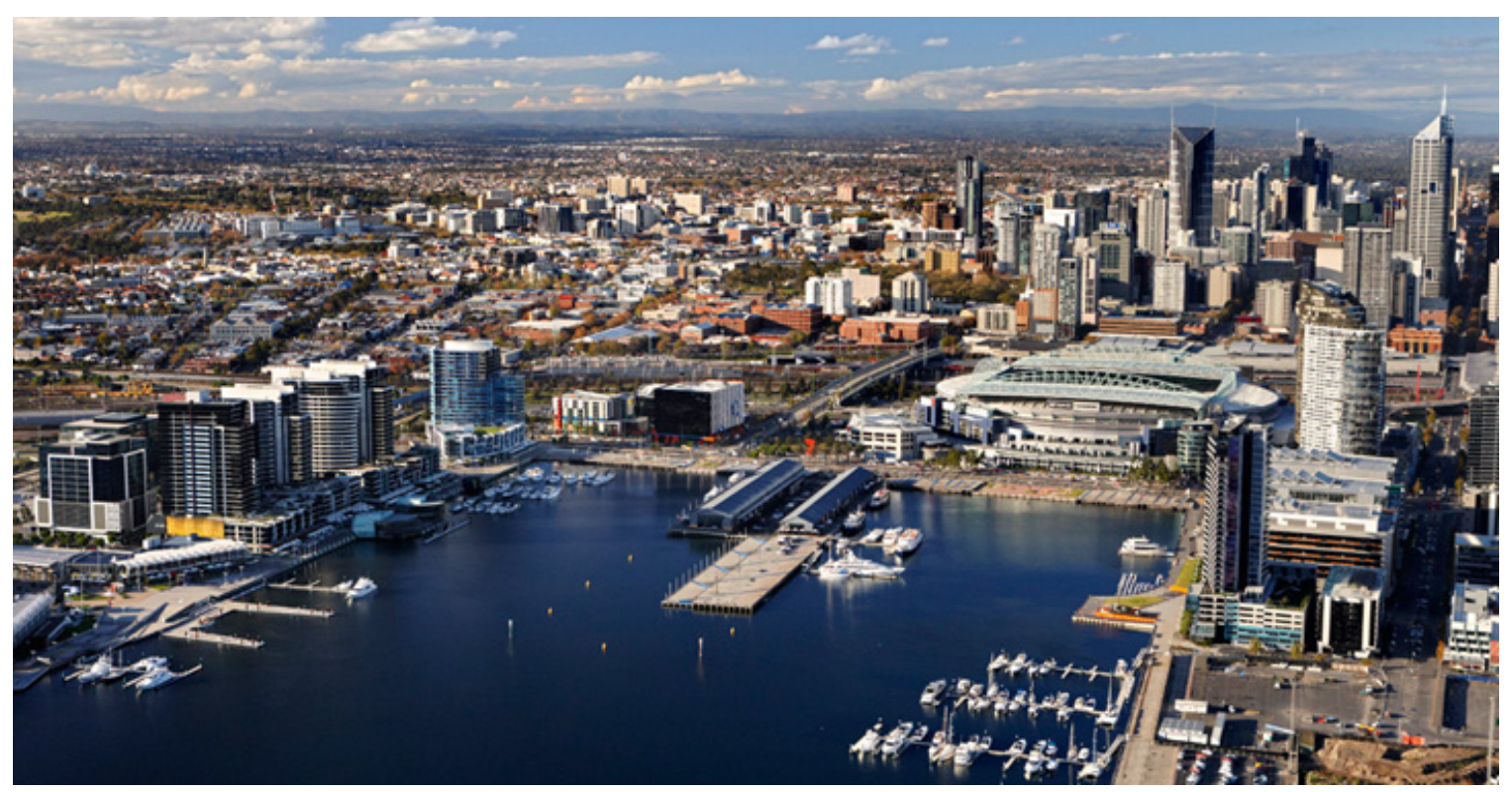

Figure 6: The Melbourne Docklands (with development)

Renew Australia began by seeking the interest of private property owners with empty spaces who would be open to permitting the temporary use of their otherwise unoccupied buildings. Renew Australia then organized the 'Expressions of Interest' campaign intended to attract artists, creative projects and community initiatives. Interested participants were encouraged to submit project proposals that had the potential to be commercially viable and deliver value to the area (Dockland Spaces, 2012). The intent of this pre-process was to match property owners with selected creative enterprises and to craft temporary occupancy license agreements.

Renew Australia acts as an intermediary agent between the property owner and the user; they negotiate with property owners, match unoccupied buildings with suitable creative projects and control the participation agreements for approved projects. Selected projects are only required to pay a small weekly participation fee to cover public liability insurance and operating costs. The default agreement between an owner and temporary user is structured as a license, rather than a lease, and permits temporary users access to the property on a rolling thirty-day basis where property owners, after 
giving thirty days notice, can repossess their properties. In sum, temporary users are trading a lack of security for a lack of rent and according to Renew Australia, "this is one of the key reasons that properties are made available rent-free and why this opportunity is best suited to creative enterprises wishing to experiment or test the viability of operating in a commercial space, not those who need the security of a lease" (Dockland Spaces, 2012). While both commercial and not-for-profit projects are encouraged, the objective is to support creative projects that have the potential to eventually operate commercially without support. If users do begin to generate profits that align with commercial standards, there is an opportunity for the creation of stable, long-term contracts including the payment of rent to property owners.

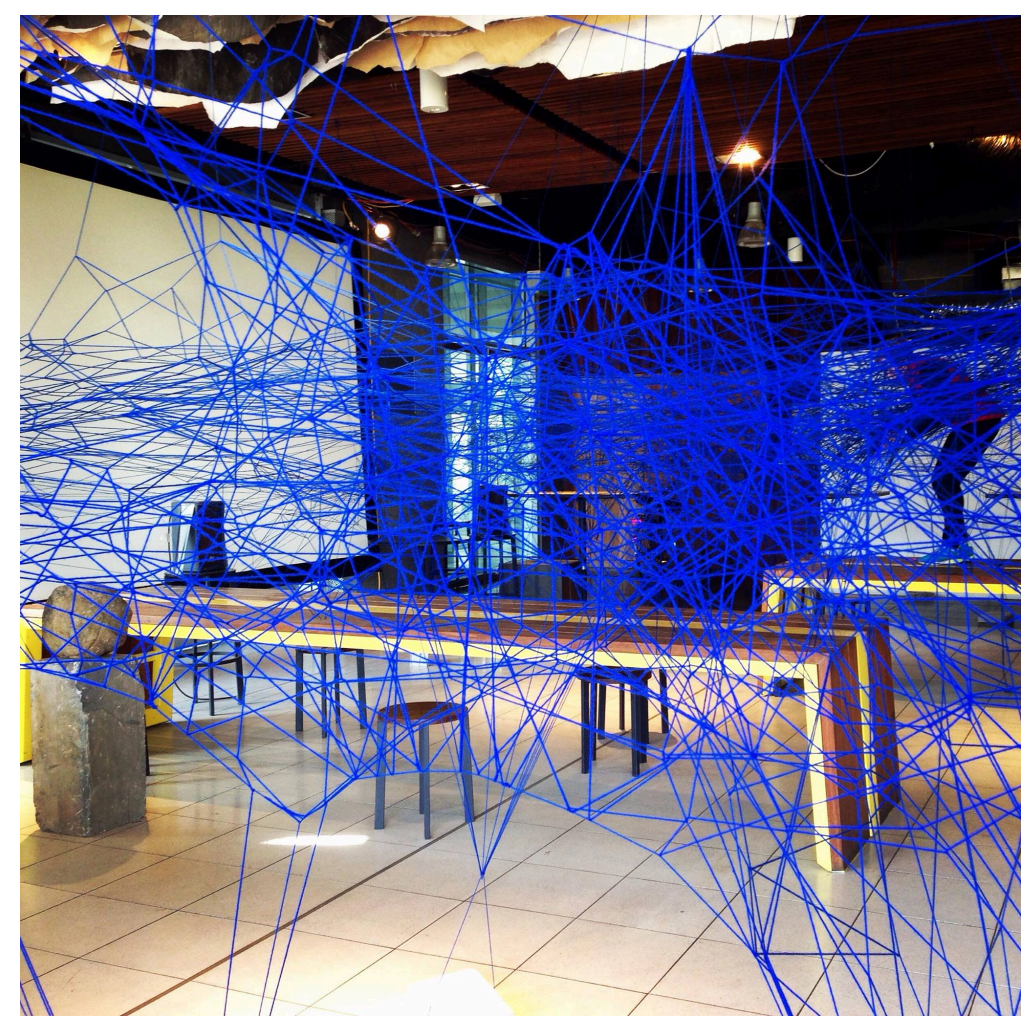

Figure 6: Gallery at the 'Food Court'

In order to select projects, Renew Australia assesses each proposal individually and also considers the compatibility of projects collectively. According to Renew Australia, a good project is one that (1) contributes to the life of the local community; (2) attracts new visitors; (3) showcases original work; (4) is easily implementable and achievable; (5) demonstrates a high degree of professionalism; (6) makes use of the 
space for a minimum of thirty days; (7) does not compete with existing commercial tenancies; (8) and has revenue-generating capacity (Appendix B) (Dockland Spaces, 2012). As of 2015, the Dockland Spaces Pilot Initiative has provided space for more than ten creative initiatives including an art and studio space, an architecture practice, a digital design company, an industrial design company, a bi-monthly magazine, a multiplatform retail social enterprise, and a place-making and visual merchandising firm (Places Victoria, 2015a). The Renew Australia program has become a model for broader policy-making and subsequent implementation (Lehtovuori \& Ruoppila, 2012). Dockland Spaces has become a tool to encourage open-ended experimentation, embrace placemaking and create positive change in the Melbourne Docklands.

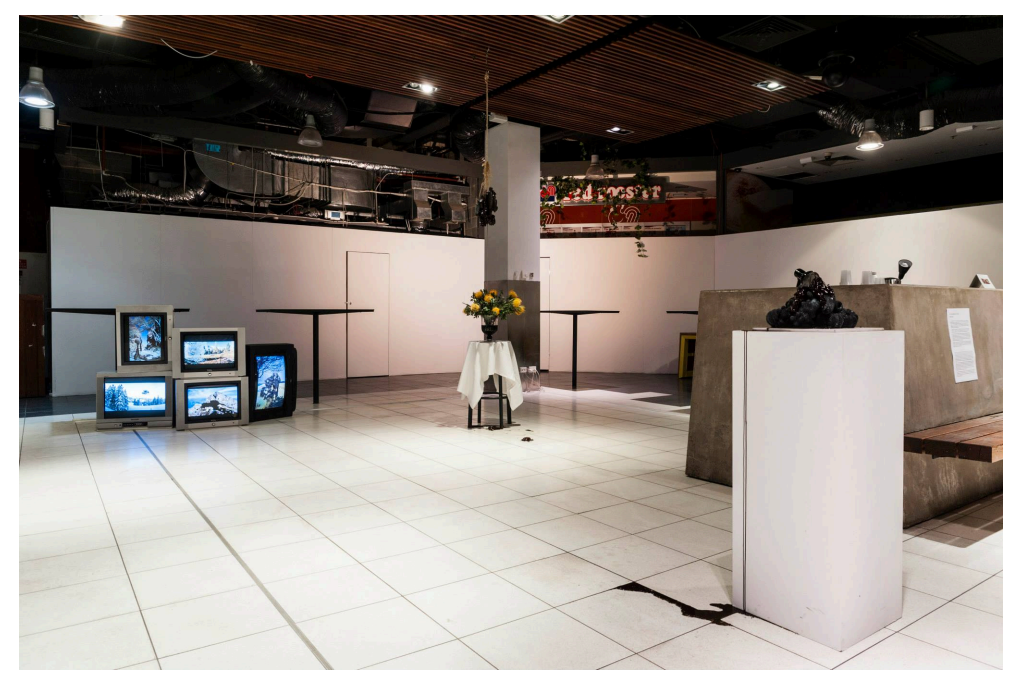

Figure 8: Gallery at the 'Food Court'

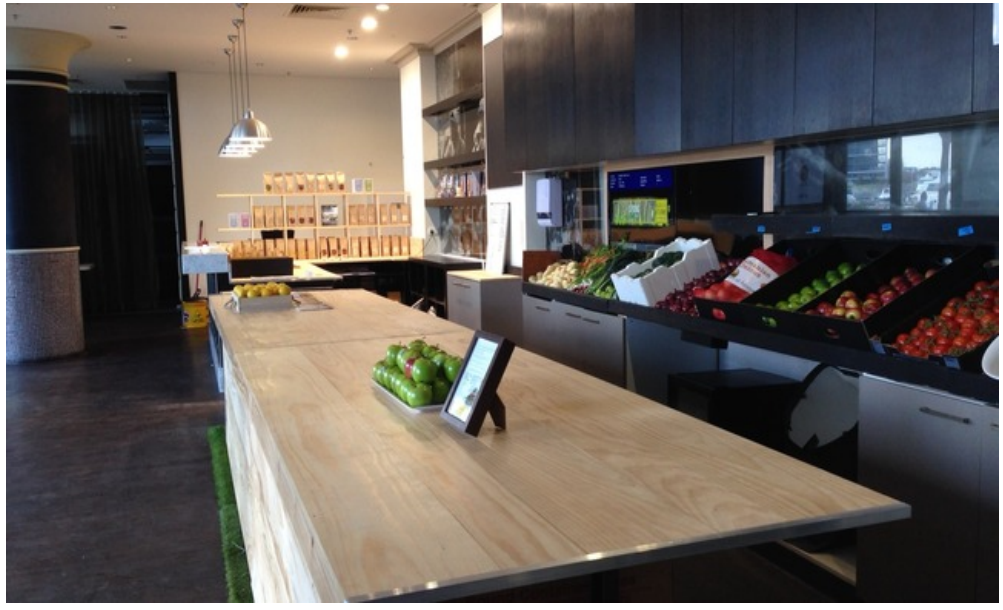

Figure 7: Dockland Spaces Project - Kelly Cube 


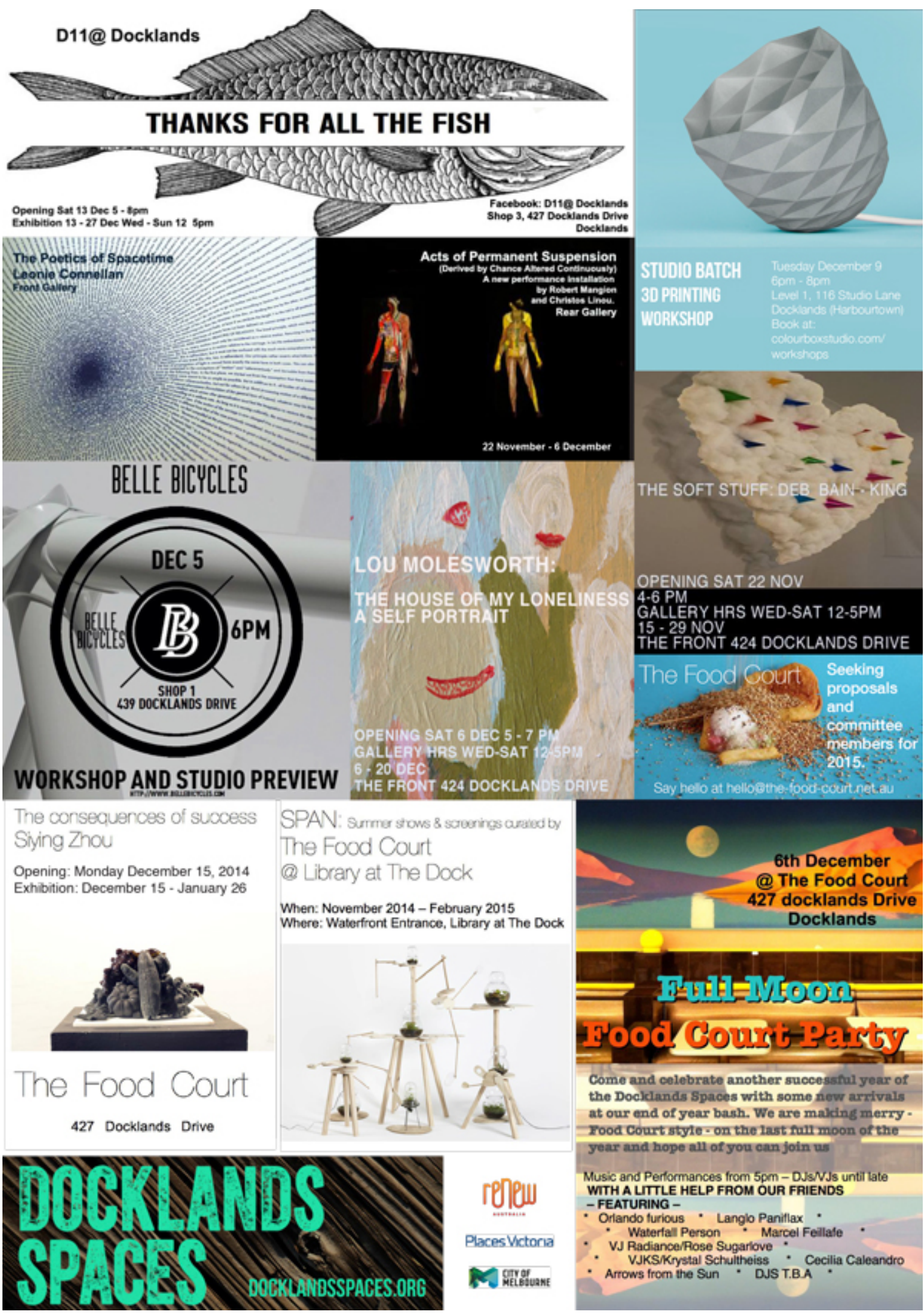

Figure 9: Dockland Spaces - Projects \& Events 


\section{NDSM Amsterdam}

The NDSM wharf, a former shipyard located along the north bank of the river lj in Amsterdam, is a leading example of the catalyzing power of temporary use. As Lehtovuori and Ruoppila (2012) explain, "the success of NDSM has changed the fortunes of the whole of Amsterdam North, triggering a wave of new developments...NDSM has become a catalyst with city-wide and even regional significance" (42-8). Oswalt et.al $(2006 ; 2013)$ explain that, in many cases, temporary uses need the support of key agents, such as municipal figures, who have access to resources and practical skills. In this case study, the Municipality of Amsterdam North (SDAN) implemented several targeted temporary use interventions and partnered with local communities to ease the access to vacant locations for temporary users. Finally, in order to catalyze redevelopment, temporary users were set in place in parallel with longer-term plans (Studio Urban Catalyst, 2003).

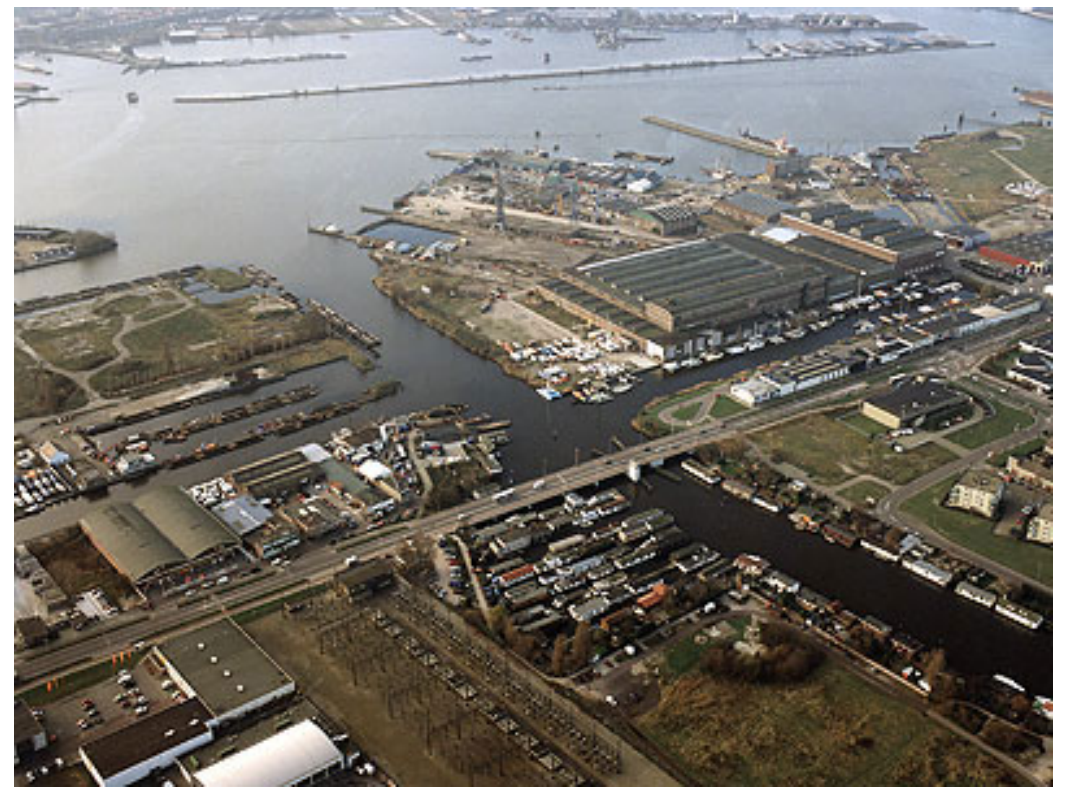

Figure 10: Northern lj bank, former NDSM shipyards

Amsterdam is the capital and most populous city in the Netherlands, as well as its cultural and economic core, and is recognized as one of the most diverse cities in the world (Source). The city is divided by the river IJ and for much of the $20^{\text {th }}$ century, its northern embankment was characterized by heavy industry and port-related activity. Similar to other post-industrial cities, Amsterdam's harbour and port industry fell idle with 
the containeration of the shipping industry and ceased to be economically viable. The Municipality of Amsterdam North was eager to encourage new industrial development in the area but found little success. For years, the space was used for illegal activities such as raves. Eventually, the harbour area was integrated into a citywide development plan where it was identified as a proposed neighbourhood. According to the plan, development would be grouped around the empty NDSM shipping hall, which would become "the engine and nucleus of the entire town planning development of the NDSM area" (Oswalt et al., 2013, 356).

In 1999, SDAN, who wished to re-establish a degree of control over the area and catalyze new development, conceived a concept that encouraged the temporary appropriation of the shipyard hall and launched a public competition in favour of creative industries (Oswalt et al., 2013; Bishop \& Williams, 2012). The competition was won by Kinetisch Noord, an alliance of artists, architects and performers, who envisioned dividing the 20,000 square-metre hall and the adjacent open dock into four thematic zones ("Kunststad"; "Nordstrook" "Oostvleugel”; and "Dazzleville") (Lehtovuori \& Ruoppila, 2012). Along with the creation of these zones, the group provided affordable space for theatre groups, handicraft enterprises, studios, start-ups and performance spaces. SDAN was able to finance the competition and invest in the redevelopment of the hall through the 'Broedplaatsfond Amsterdam' - a tool and an 'earmarked' fund used to promote the city's creative industries. Kinetisch Noord provided the basic infrastructure for studio spaces that were eventually completed by end-users to save costs and encourage participation (Bishop \& Williams, 2012). The benefits that this process afforded the city were twofold. First, the well-publicized competition provoked strong public interest and heightened the public's awareness of the NDSM site. Second, the competition allowed the city to select and shape the profile of the temporary users (Oswalt et al., 2013). For example, the municipality was able to define and set-forth conditions that potential temporary users had to accept in order to participate. 


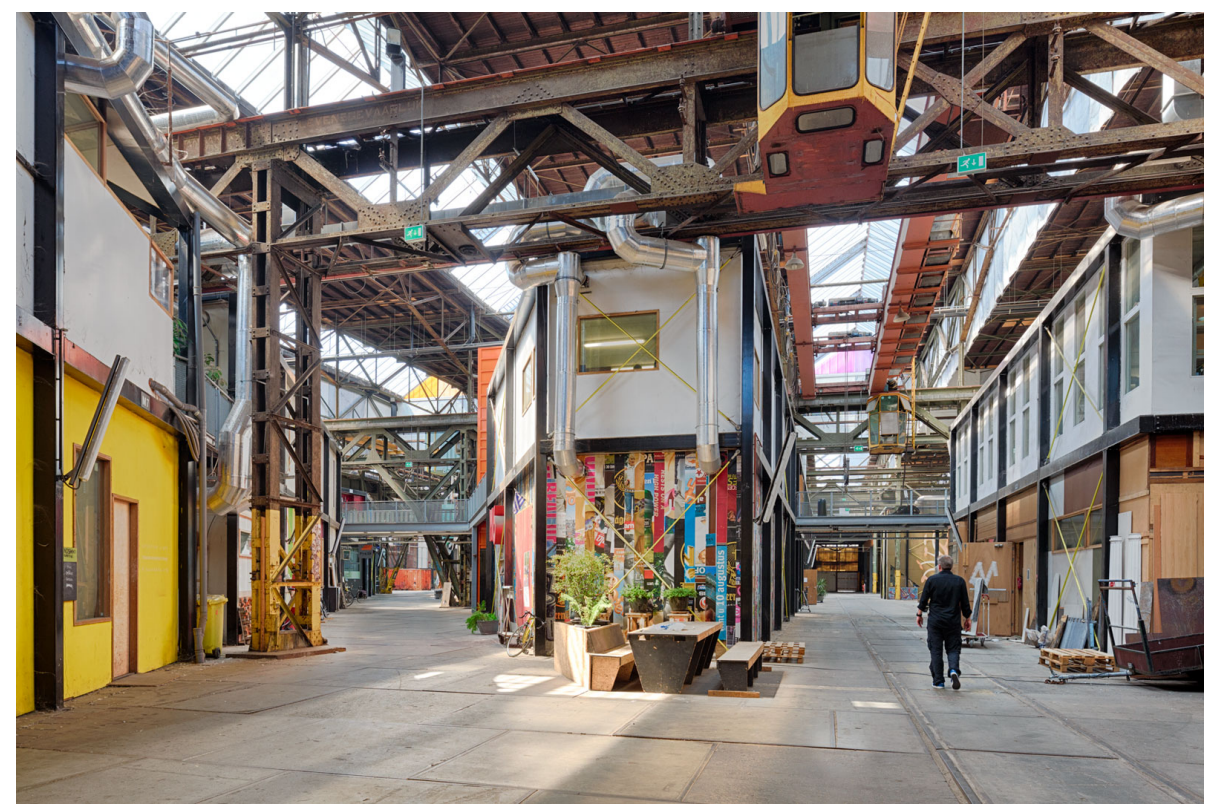

Figure 11: "Kunststad": Art City in the NDSM wharf

SDAN also contributed to the area's development in a variety of ways. For one, the SDAN lobbied the city of Amsterdam to provide a ferry service to link the northern embankment to the central city area across the $\mathrm{IJ}$ and subsidized the ferry itself for the first two years. The municipal council also renovated the former wharf canteen to provide a restaurant and office spaces and introduced temporary student housing in disused shipping containers. In 2003, SDAN commissioned STEALTH Unlimited to prepare a strategy for the application of temporary uses in combination with a long-term vision for regeneration (Bishop \& Williams, 2012; Oswalt et al., 2013; Lehtovuori \& Ruoppila, 2012). STEALTH Unlimited explains that their framework encourages fluidity so that "developments can respond to the changing reality during the twenty-five year [planning and implementation] trajectory" (STEALTH Unlimited, 2003). STEALTH has also created (1) a database which links potential users to sites, (2) a platform which "stimulates, coordinates and offers expertise - both to temporary users and to the project managers responsible for the area" (STEALTH Unlimited, 2003), and (3) a new planning tool to handle the "time-space occupation of the area" (STEALTH Unlimited, 2003). This tool illustrates alternative programs and other possibilities that could exist on a site between its existing use and its planned use. 
The NDSM complex now hosts over 200 sociocultural uses, several hundred jobs, a skate park, cafés, flea markets, studio spaces and cultural events. SDAN still encourages low rents and encourages a vibrant mix of uses and creative enterprise. The approach taken by SDAN illustrates that temporary uses can be employed in combination with long-term plans while the work of STEALTH reaffirms the significance of process-oriented approaches that reflect the changing of needs and circumstances.

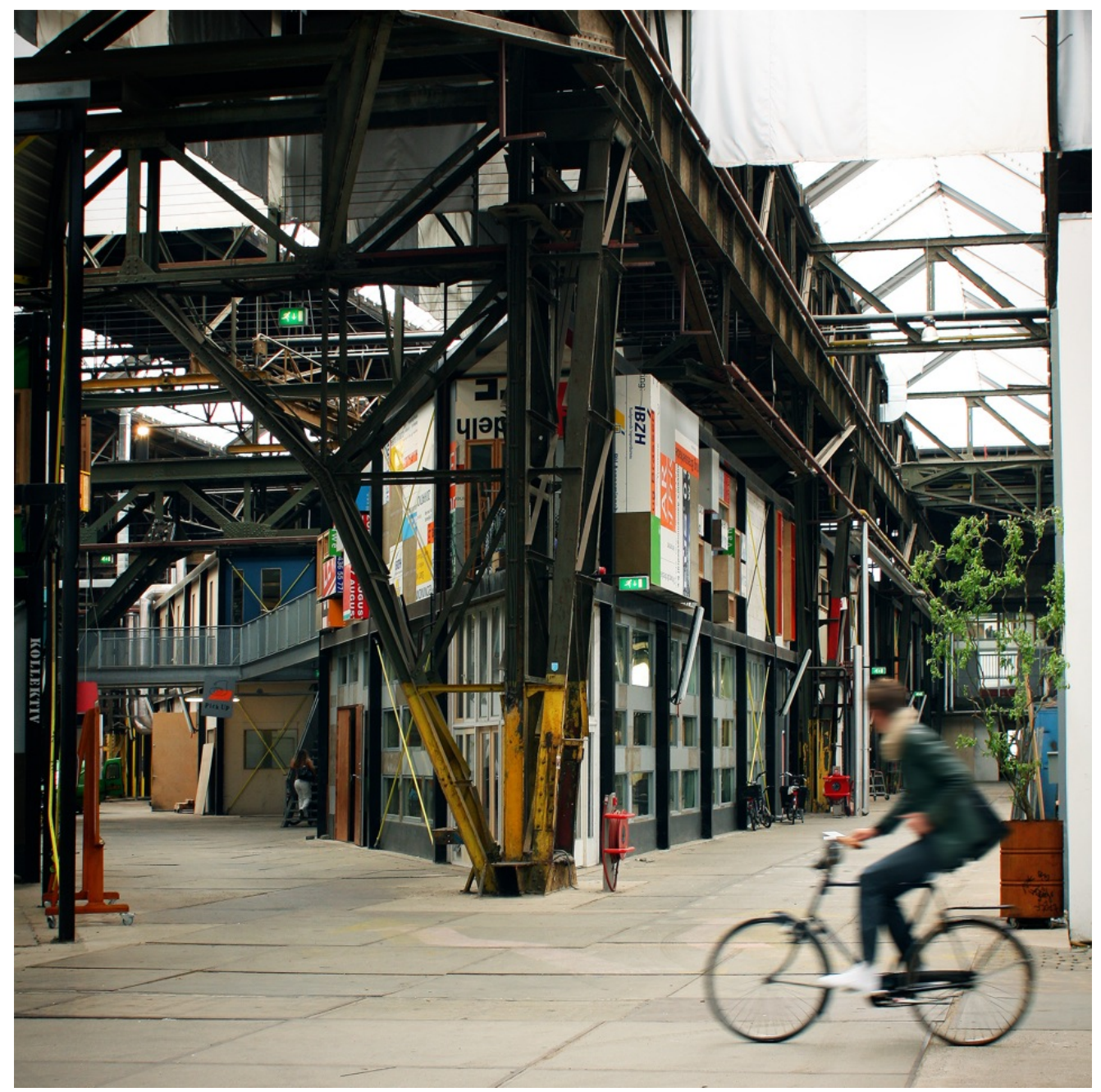

Figure 12: Studio spaces in the NDSM wharf 


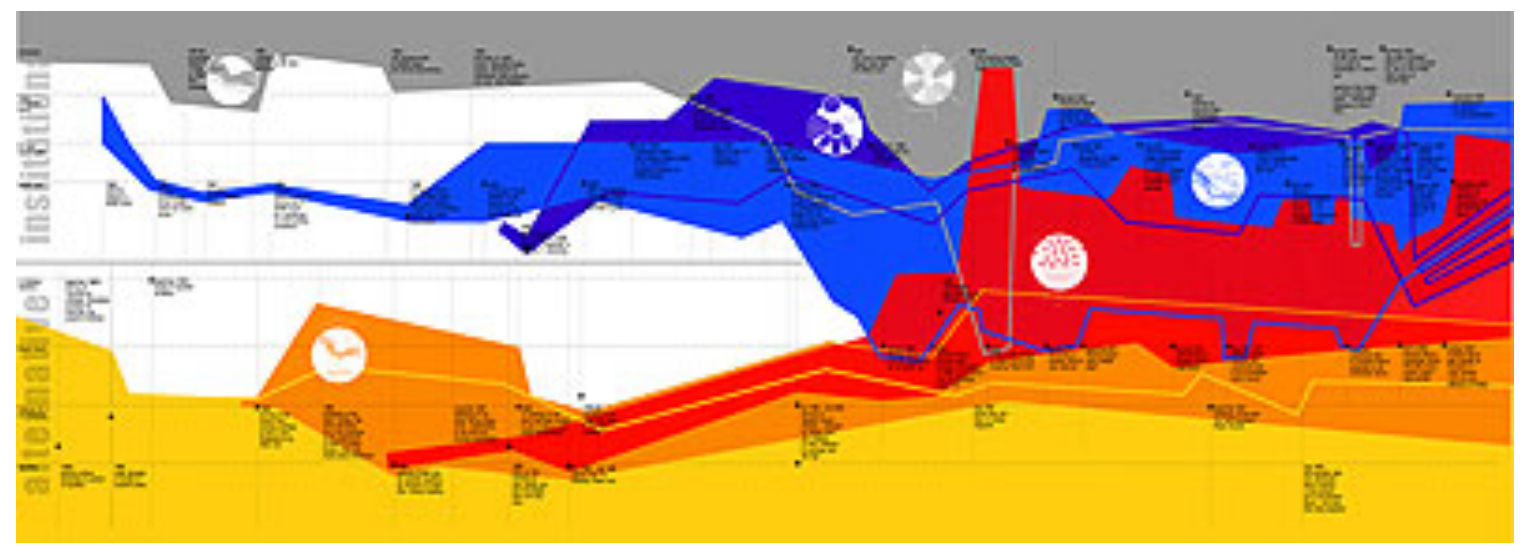

Figure 13: Diagram showing change in relations (from 1980's till 2003) between alternative (squatting: yellow/orange) and institutional (city: blue) forces in Amsterdam towards unusual coalitions
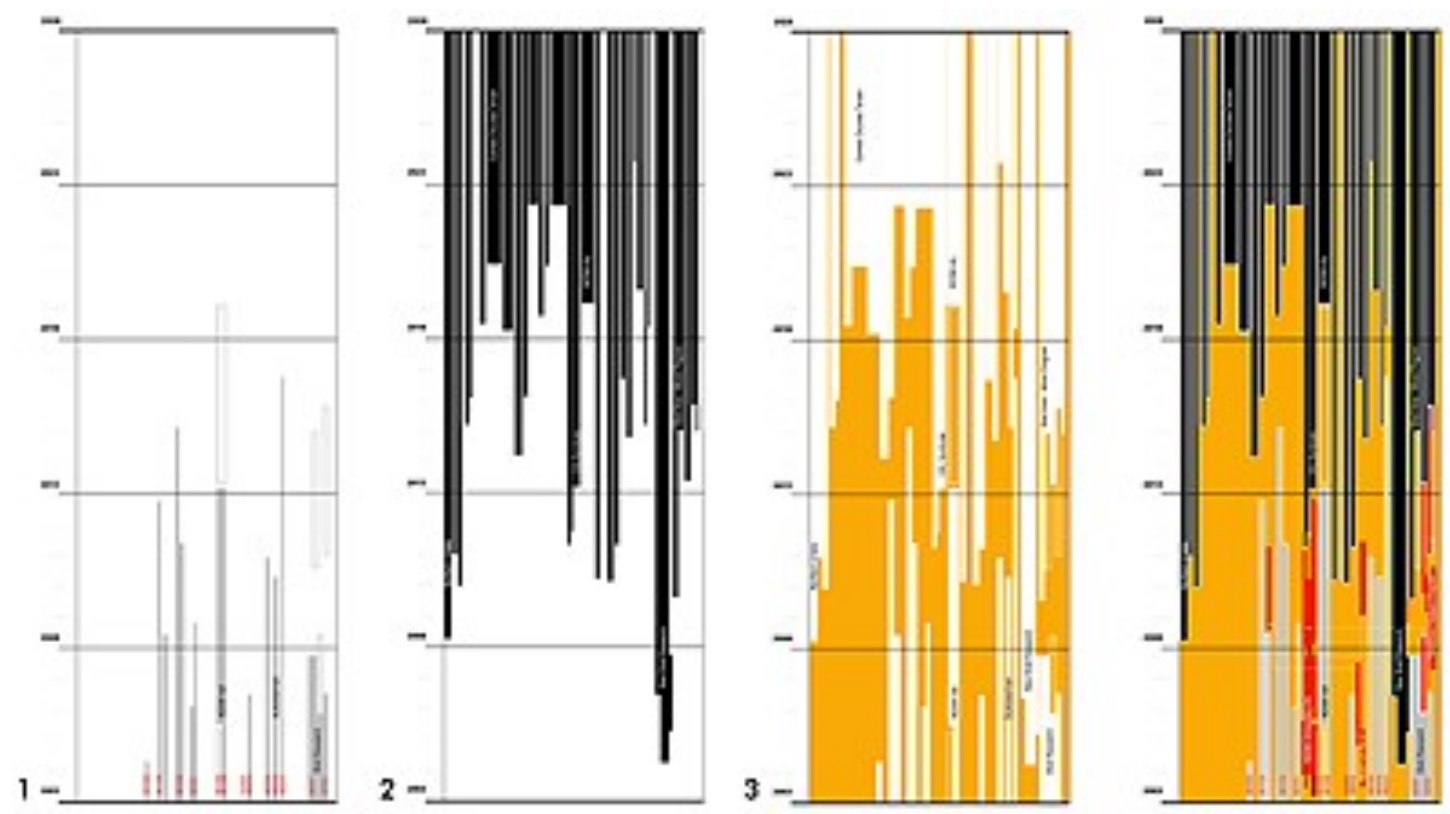

Figure 14: Space/Time diagram: 1 - existing use, 2 - planned, 3 - time/space gap, showing possibilities for alternative programs to enter the redevelopment process 


\section{IBA Hamburg}

The Internationale Bauausstellung or International Building Exhibition (IBA) is an urban renewal instrument that showcases new and innovative ideas to the planning and architecture communities. While IBA's have been wholly used in Germany since 1901 as vehicles to explore new forms of architecture, urban development, city development, community engagement, city branding, economic renewal and environmental rehabilitation (Smith \& Ferrari, 2012; Shay, 2012), the IBA model attempts to provide solutions towards city-making that can be instrumentalized in other locales (Shay, 2012). Over the course of the $20^{\text {th }}$ century IBA's occurred every 15 to 20 years. However, the number of active IBA's (3 occurring simultaneously in 2012) has increased substantially demonstrating that the IBA model is gaining influence and momentum in Germany and Europe. As noted, the IBA model is focused on developing innovative solutions to contemporary issues such as deindustrialization, shrinkage, urban growth, and revived interest in the inner urban core. Although the earliest building exhibitions were largely presentations of modern architecture (1901 Mathildenhole; 1910 Berlin), the more recent IBA's, such as IBA Hamburg and IBA Emscher Park, have also tackled the regeneration of industrial landscapes and have become workshops, labs and instruments of visionary urban development with a sound focus on social, economical and cultural matters (IBA Hamburg, 2014a). In Hamburg, the IBA sought to (1) deal with the growth of the city without succumbing to sprawl, (2) reposition the immigrant population as an asset for the metropolis and, (3) encourage environmentally sustainable future growth. This case study will explore the implementation of 'IBA Hamburg' as a tool to uncover experimentdriven solutions to environmental change, cultural contestation and derelict innerperiphery spaces.

Shay (2012) explains that, in composition, IBA's are characterized by being "siteand time-specific, long-term and temporary, driven by experimentation and independent in their urban development role" (16); they are steered by "theoretical and practical experimentation and a goal to produce 'models for the city of the future' that address paradigmatic shifts in urban development" (5). The IBA is called into action by a municipality to address contemporary conditions (e.g., social, economic or environmental transitions such as deindustrialization, post-war redevelopment, urban shrinkage, etc.) and to provide high-level collaborative and regenerative strategies (Shay, 2012; IBA 
Hamburg, 2014a). The IBA operates as a government-supported, independent agency (called $\mathrm{GmbH}$ ) with funding split between city and regional levels of government and national-level funding. The IBA is an independent entity, neither bound by the local government nor by the private sector, that consults each of the sectors in order to cultivate a unified development strategy (Shay, 2012). The IBA commission is not responsible for the manifestation of built projects but rather produces strategic visions, participation processes, imaging campaigns and other 'soft' instruments of development, and acts as a mechanism to inform local governments (Shay, 2012). IBA's are commissioned for a set period of time, typically between five to ten years. During this time the IBA studies a city, instigates a series of phased experimentations and develops and delivers innovative solutions to address contemporary conditions. As explained by Shay (2012), this combination of longevity and temporality "balances between the IBA's charge towards conceptual innovation and experimentation that requires research phases as well as accountability to deliver efficiently by its temporary commission" (18). The goal of the IBA is to establish unprecedented methods of planning, address paradigmatic shifts in urban development and generate innovative planning approaches and conceptual impacts with wide-reaching effects. In 2006, Hamburg commissioned the IBA to tackle the regeneration of the Elbe Islands. Given that the Elbe Islands are similar to the Port Lands in terms of contamination and derelict industry, several lessons and applicable techniques can be drawn from this case study for Toronto as it attempts to tackle similar regeneration.

The Elbe islands, including the neighbourhoods of Wilhelmsburg and Viddel, have long been described as a problem area within Hamburg with economic and social decline brought about by the westward movement of port activity (Smith \& Ferrari, 2012). The Elbe islands are located directly south of the city centre across the Elbe. However, in the eyes of many Hamburg residents, the city ends along the north bank of the Elbe. Although Wilhelmsburg is Europe's largest inhabited river island, it is only home to some 50,000 residents including a large proportion of migrants. The islands which are a patchwork of port-related, industrial, commercial, infrastructural and residential uses (Smith \& Ferrari, 2012), have been branded as a 'metrozone' - an area at the inner periphery of a large city, located outside of the city centre but within the municipal boundaries, that are described as "generally weak with [a] diverse social makeup" (Shay, 
2012, 40-1). Wilhelmsburg Islands has also experienced social difficulties including high levels of unemployment, poverty and crime (Smith \& Ferrari, 2012). Despite these identified problems, the area has been recognized as a development opportunity and a space to accommodate a growing population.

In 2004, the City of Hamburg established 'Leap across the Elbe' - an initiative to encourage the use and development of the southern areas of the city and as a means to "boost the growth of the booming metropolis" (IBA Hamburg, 2012b, para. 3). This initiative would be aided by two key events: the International Garden show and the International Building Exhibition (IBA Hamburg, 2014b; Smith \& Ferrari, 2012). The IBA Hamburg $\mathrm{GmbH}$ was established at the conclusion of 2006 with the IBA itself beginning in 2007. A pre-process, running from 2000-2007, called "Dialogues with Citizens", was part of a participatory program that sought the active involvement of citizens through a series of large-scale forums and workshops in order to identify problems and to document the desires of Wilhelmsburg residents (Shay, 2012; Smith \& Ferrari, 2012). The IBA elicited public participation in several ways and actively sought to pursue dialogue with residents, particularly immigrant groups. These forums ultimately fed into the development of IBA's three key themes. In 2005, the City of Hamburg also drafted the Memorandum for the International Building Exhibition Hamburg 2013, which detailed the intentions of the IBA; this document was the output of workshops and meetings held during the pre-process (Shay, 2012). The IBA process was flexibly structured to allow for the easy adaptation of newly arising needs and circumstances. The Memorandum document, used a policy tool used to maintain consistency across all projects, detailed a series of core concepts while allowing for flexibility in terms of the outputs of the process (Shay, 2012). Between 2007 and 2012, three themes were established by the IBA under the slogan "The Metropolis for the Future", including: Cities and Climate Change, Metrozones, and Cosmopolis (IBA Hamburg, 2014c).

The first theme, Cities and Climate Change, acknowledging, first the uncertainty of climate change itself and second, that major cities around the world are both the main cause of climate change but also victims to its consequences, focused on the creation of a climate-compatible future for the metropolis through sustainable urban energy usage, climate-neutrality, self-sufficient and energy-efficient buildings and sustainable 
infrastructure and built form (IBA Hamburg, 2012b, 2012c). The second theme, Metrozones, was established to improve the potential of the inner city peripheries and to discover the opportunities hidden, yet plentiful, in the transitional parts of the metropolis (IBA Hamburg, 2012c). The objective of this theme was to transform the metrozone spaces into quality urban areas and to encourage the mix of living and working areas. Finally, given that the area is home to some one-hundred nationalities, the objective of the third theme, Cosmopolis, was to harness this diversity as a strength and to determine "whether and/or how social and cultural barriers, within [an] urban societyand against [a] background of demographic change, [might] be overcome by means of urban development and architecture" (IBA Hamburg, 2012d).

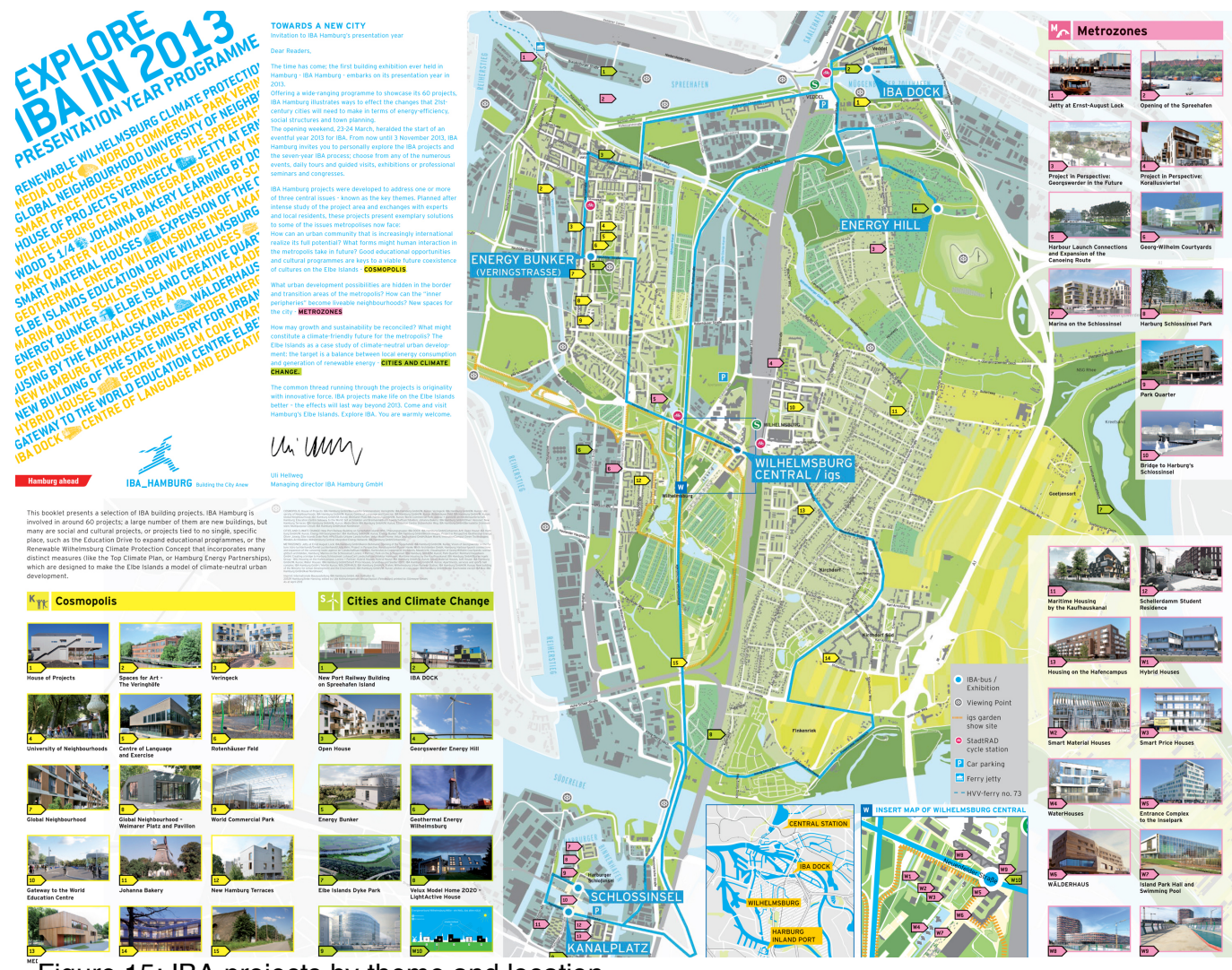

"Figure 15: IBA projects by theme and location

By 2013, the presentation year, over seventy projects had been implemented ( 23 for Cosmopolis; 33 for Metrozones; and 14 for Cities and Climate Change). Several of these projects, such as The Academy of Another City and University of Neighbourhoods, are temporary and experience-based projects while a variety of others are built and programmatic. These seventy projects transpired in a variety of ways including calls for ideas by the IBA and proposals submitted by organizations, developers, community 
groups and individuals. While IBA projects were implemented by a number of groups, each project had to meet the IBA Excellence Criteria, proving its originality, feasibility, innovation, support of the key themes and contribution to the area (Appendix C). An annual evaluation process with targets and indicators (e.g., energy consumption rates, signs of gentrification, etc.) is also run for each project individually and for the IBA as a whole (refer to Appendix D for the full list of implemented IBA projects by theme).

IBA Hamburg has been used as a tool to reactivate and resituate the Elbe islands. Temporary interventions and experience-based projects have played a key role in stimulating public support and public input (Shay, 2012). The IBA reconciles the disciplines of architecture, planning and urban design in order to create unconventional solutions to contemporary urban conditions through experimentation.

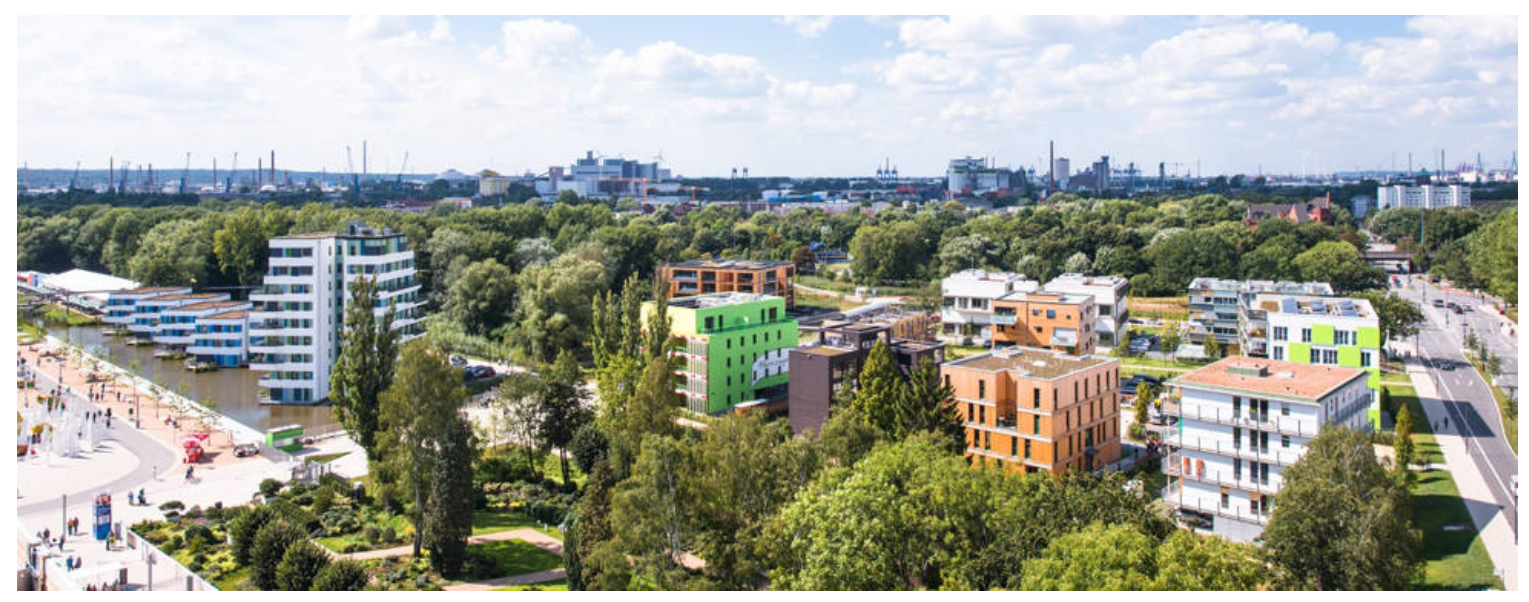

Figure 16: Elbe islands post 2013

Adaptive design, described as the process of learning through conscious and collaborative experimentation, is a relatively new concept in the field urban planning. This approach combines design and practical planning with theoretical research and scientific methodology in an inclusive environment. Given that planning decisions and policies are made in the face of uncertainty, the application of experimentation and integrative and deliberative design is critical in order to create an approach to planning that is adaptive, resilient and responsive to uncertainty and change. As described by Lister (2010), "the adaptive context is one where learning is a collaborative and conscious activity, derived from empirically monitored or experientially acquired 
information, which in turn is transformed into knowledge through adaptive behavior" (528). In practice, adaptive and experimental planning can serve as a mechanism for socio-structural feedback as well as a tool to cultivate interaction, impulse and dialogue among community members and people involved in the planning process. The results of designed experiments might establish new visions, organizational arrangements, and scenarios for urban space and fabricate socio-spatial transformations that are adaptive and responsive to changing needs. 


\section{Chapter 5: Analysis}

"Globalization of technologies, societies and economies is transforming the world along diverse and unforeseen pathways" (Bowring \& Swaffield, 2013, 96), and the disciplines of planning, urban design, architecture and landscape architecture are confronted by a need to both respect the past and confront uncertainty. As Marshall (2001) explains, our cities are changing at an unprecedented pace yet some conventional ideas seem at odds with the current reality of contemporary culture and society. For decades, the planning and design professions have tended to view space in a more productive way than time; however, cities evolve in both space and time. Nevertheless, planners have come to realize that traditional planning processes do not provide solutions to 'wicked problems' - those with no simple solutions, unknown answers, and multiple elements (Rittel \& Webber, 1973) - and have come to recognize that a homogenous worldview simply does not exist. Planners must continue to embrace uncertainty and plan adaptively. As Marshall (2001) explains, what is needed is a further "re-calibration of our ideas to the currency of our time" (Marshall, 2001, 3). This requires an appreciation for and an acceptance of temporary uses and interim phases of development as legitimate tools in the planning and design processes.

Krieger (as cited in Marshall, 2001) argues that it is along its waterfront that the aura of a city resides and persists. Similarly, Marshall (2001) explains that waterfronts serve as highly exposed platforms for representing the city (2001). Waterfronts have become a terrain of availability and provide an opportunity for new city-making and place-making paradigms. While the rediscovery of waterfronts is becoming a welcome global trend, city authorities often lack the resources, control and fiscal capital to develop their waterfront spaces. Waterfront redevelopment projects have also become synonymous with economic investment, tourism, capital and "visions of exuberance", and are often thought of as an urban panacea to many contemporary issues (Marshall, 2001). The Port Lands will eventually be developed however there is no need to rely on development models that fail to acknowledge the importance of time and the significance of the 'lived experience' (Crawford, 2012); such product-oriented thinking fails to consider the city as an "ever-changing but essentially temporal phenomenon" (Bishop \& 
Williams, 2012, 220). In the absence of certainty and predictability, temporary uses provide an outlet for adaptive planning, design, and management strategies.

The Urban Catalyst team has been a key contributor to current research and discourse on temporary use. Since the early 2000s, the Urban Catalyst team has explored the potential of both unplanned and planned temporary uses. Based on their research, as well as their experiences and participation in a number of temporary use projects around Europe, the team concluded that spontaneous, temporary uses can have positive long-term effects and can be successfully incorporated into the planning processes (Oswalt et al., 2006). Their years of practice and research have demonstrated that temporary uses can became a vehicle to, not only provide, but also promote opportunities for new and unplanned activities. In doing so, temporary uses can transform the banal, commonplace and everyday spaces into breeding grounds for innovative cultural production (Oswalt et al., 2006; Oswalt et al., 2013).

\section{The City as a Laboratory}

Greenberg (1996) explains that it is only through the physical manifestation of actual plans and real projects that the strengths and weaknesses associated with each can be understood and evaluated. This approach sees the city as a creative laboratory where scale-appropriate experimentation and incremental planning provide an opportunity for informal learning and collaborative and conscious activity, where "the failures [of an experiment] are often as informative as the outright successes" (Greenberg, 1996, 217). Responsive and responsible experiments, exhibited in a "safeto-fail" environment, allow for observation, reflection and evaluation (Lister, 1998, 2000, 2010).

\section{Adaptive Management and Experimentation}

According to Kato and Ahern (2007), adaptive management (also called adaptive design by Lister, 1998, 2000, 2010) is a well-established method in natural resource and ecosystem management, but is yet to be widely applied and integrated into planning. They explain that adaptive management actions are best understood and practiced as experiments, implemented simultaneously, where results are monitored; knowledge is then understood and gathered through the practical application of controlled experiments 
in a 'learning-by-doing' setting and in a safe-to-fail environment (Lister, 2010). Similar to Greenberg (1996) and Lister (1998, 2000, 2010), Kato and Ahren (2007) explain that planners need to accept and acknowledge the potential to fail; however, this also implies the corollary: the possibility to succeed. They further explain that "the culture that encourages experimenting with new approaches and considering new information needs to be embraced by [planners] and the risk of 'controlled failures' needs to be accepted as part of the process, not as an indication of incompetence by planners" (555). This acknowledgement might also be facilitated through an awareness of other successful projects or through continuous professional learning.

\section{Temporary Uses as a Strategic Component of Planning \& Design Processes}

The case studies in Melbourne, Amsterdam and Hamburg illustrate that temporary uses can successfully operate in a variety of socio-spatial contexts and can be used as a strategic component in the planning, design, development and management of cities and sites. These case studies re-emphasize that temporary uses can have a variety of social, cultural, economic, development-focused and place-making benefits and can be effectively integrated into conventional planning and design methods. These three case studies are particularly relevant to the Port Lands in Toronto because each is in a state of transition and all share similar social and cultural circumstances. Similar to Qviström's (2004-2009) research on ephemeral landscapes located at the urban-rural divide, the Elbe islands in Hamburg are situated in a 'metrozone' - an area at the inner periphery of a large city, located outside of the city centre but within its municipal boundaries and described as "generally weak with [a] diverse social makeup" (Shay, 2012, 40-1). For decades Wilhelmsburg and Viddel have been marginalized and underserved by public transit and infrastructure and have had to struggle with disinvestment in services. Furthermore, the neighbourhood is home to a large migrant and socio-economic population. The Port Lands share many traits with the periphery and metrozone landscapes. Toronto, perhaps to an equal or lesser degree, experiences similar socio-economic polarization and is just as ethno-culturally diverse. The NDSM neighbourhood in Amsterdam was left neglected and contaminated for years and several plans failed to absorb the vast space. Similarly, several plans have been drafted for the Port Lands however the area remains in a state of anticipation and uncertainty. Finally, the Melbourne Docklands, similar to NDSM, was also left neglected 
for years until the 1990's when the area was recognized for its development potential. Following a decade of development, the City of Melbourne had to re-evaluate its approach in order to encourage a more collaborative and engaging user environment. Melbourne shares a similar political and economic context with Toronto where development sometimes encourages the involvement of private enterprise much to the dismay of urban citizens.

As part of a design-based workshop in Aalborg in 2005 (Harbourscape), Bader et al., (as cited in Kiib, 2012) recommended a variety of process-oriented planning approaches and procedural strategies that could be used to exploit the potential of the time gap existent in urban voids like post-industrial waterfronts. A prime example of design-based research, they recommended that: key agents get involved in supporting informal networks and strategic coalitions; a strategic plan be created to prioritize key areas for different temporary-use typologies; spatial structures and existing resources be reused where warranted; a negotiation platform be created to combine formal and informal development; waiting spaces and time gaps be identified for potential activist networks; and flexible strategies be followed, which allow temporary activities to become permanent or close down if necessary (Kiib, 2012, 134). These recommendations serve as useful frameworks when both describing and evaluating the results from the aforementioned case studies.

\section{Partnerships and Strategic Coalitions}

In all cases, municipal figures and intermediary organizations commissioned by municipal authorities (Renew Australia, IBA, STEALTH) played a proactive role in the materialization and support of temporary uses. In Melbourne, Renew Australia, commissioned in joint by the City of Melbourne and Places Victoria, encouraged property owners to lend their properties for temporary uses and linked otherwise unoccupied buildings with creative enterprises and community initiatives. In Amsterdam, SDAN encouraged the temporary appropriation of the shipyard hall and launched a public competition in favour of creative industries. SDAN and Kinetisch Noord were then able to forge micro-level partnerships with artists, architects, performers, start-up groups, and other 'weak actors'. SDAN also contributed to the area's development through a variety of networking, marketing and promotional tools. For example, the well-publicized 
competition, coupled with the subsidization of ferry and the renovation of the wharf canteen triggered a strong and widespread public interest, encouraging more residents to visit Amsterdam North. SDAN also introduced temporary student housing in a development of shipping containers. While shipping containers are a common feature of many temporary interventions worldwide, Bishop and Williams (2012) explain that Dutch land-use zoning, which is said to be quite rigid in nature, would not have allowed permanent housing development in containers; therefore, "the public authority had the boldness and imagination to subvert [...] its own policies" (177). In this example, SDAN adjusted its own policies and regulations to provide a more permissive, flexible and relaxed environment conducive to temporary uses. STEALTH Unlimited, again appointed by SDAN, created a database linking potential users to sites and a platform to offer expertise and advice to temporary users and project managers. In Hamburg, it was the city that commissioned and financially supported the IBA. The two entities then forged partnerships with community members and private organizations in order to collectively determine a series of unified and collaborative solutions. This collaboration also engendered a strong sense of ownership thereby encouraging residents to socially invest in Wilhelmsburg and Viddel.

\section{Encouraging Innovation with Minimal Resources}

In Hamburg, Melbourne and Amsterdam, spatial structures and existing resources were reused and recycled, where warranted. In Amsterdam, the old NDSM shipping hall served as both the engine and the core of the entire development of the NDSM area. The space was used as a thematic hall with hundreds of users and studio spaces and basic infrastructure was provided from already available resources. In Melbourne, creative enterprises were able to use unoccupied buildings for temporary activities and in Hamburg, many of the seventy projects made use of existing buildings.

\section{Flexible Strategies and Approaches to Development}

The transitional and ephemeral uses implemented were flexibly structured in each of the three cases. In Melbourne, the permit system was deliberately made to be elastic in practice. The creative enterprises and community groups were able to test the viability of their projects in a safe-to-fail environment without having to pay rent on a rolling thirty-day basis. If their temporary projects began to generate profit and operate 
commercially without support, the projects could become permanent. In Amsterdam, the long-term plans prepared for the NDSM neighbourhood have flexibility strongly embedded within, allowing development to occur in a series of incremental phases where temporary uses and loosely defined visions are implemented in conjunction with the longer-term plans. This approach allows developments to respond to the evolving social and physical characteristics of the area, and adapt to unforeseen contingencies and vicissitudes of the market place during the estimated twenty-five year development trajectory. Similarly the temporary use masterplans created by STEALTH have sought to exploit the time gap existent between present and future circumstances in order to increase overall functionality and productivity during fallow time.

\section{Paradigmatic Shifts and the Inclusion of Multiple Publics}

As previously described, the IBA is called into action by a municipality to generate solutions that appropriately address specific paradigmatic shifts in urban development. In the case of Hamburg, two of the key tasks of the IBA were to improve the potential of the inner city peripheries and to broaden the community of users. The inner and outer neighbourhoods of Hamburg are described as being relatively stratified the inner core is being actively intensified and redeveloped while the outer core is increasingly disvalued (Shay, 2012). Prior to the IBA, Wilhelmsburg and Viddel were described as largely invisible and vaguely understood and were seen as "non-places with scattered industrial areas, poor immigrant neighbourhoods and [...] a banal public realm" (Shay, 2012, 52). The IBA immediately placed its emphasis on making the inner periphery more visible to the city and constructing a new image for the area. While inner periphery areas are common in most cities, Hamburg had to ensure that growth, regeneration and re-characterization of the Elbe islands did not displace existing migrant communities. In order to do this, the IBA actively encouraged the involvement of many cultural and socio-economic groups. Slogans, such as 'planning - having a say' and 'helping to shape your neighbourhood' were created to get citizens actively involved in the redevelopment of the area. A series of successful projects, corresponding to the 'Cosmopolis' theme, were then created to ensure that residents had a part in the shaping of the area. For example, projects such as the Rotenhäuser Feld, the Global Neighbourhood, MultiCoolti Park, Multicultural Public Spaces and Elbe Islands Creative 
Quarter, were founded and used to strengthen tolerance and create intercultural spaces for the growing international population.

In these examples, project coordinators worked with migrant citizens in opendialogue and in their native tongues in order to ensure that multicultural residents and user populations were well-informed and included in projects. Furthermore, the 'Dialogues with Citizens' participatory program also sought the active involvement of citizens through a series of large-scale forums and workshops in order to identify problems and to document the desires of Wilhelmsburg residents before the initiation of the IBA. This approach seems to be much more aligned with the notion of 'the right to the city', first conceived by Lefebvre (as cited in Fincher \& Iveson, 2008), where citizens are granted the opportunity to claim some kind of shaping power of the processes of urbanization. The IBA stimulated a sense of ownership and encouraged the social investment of multiple publics.

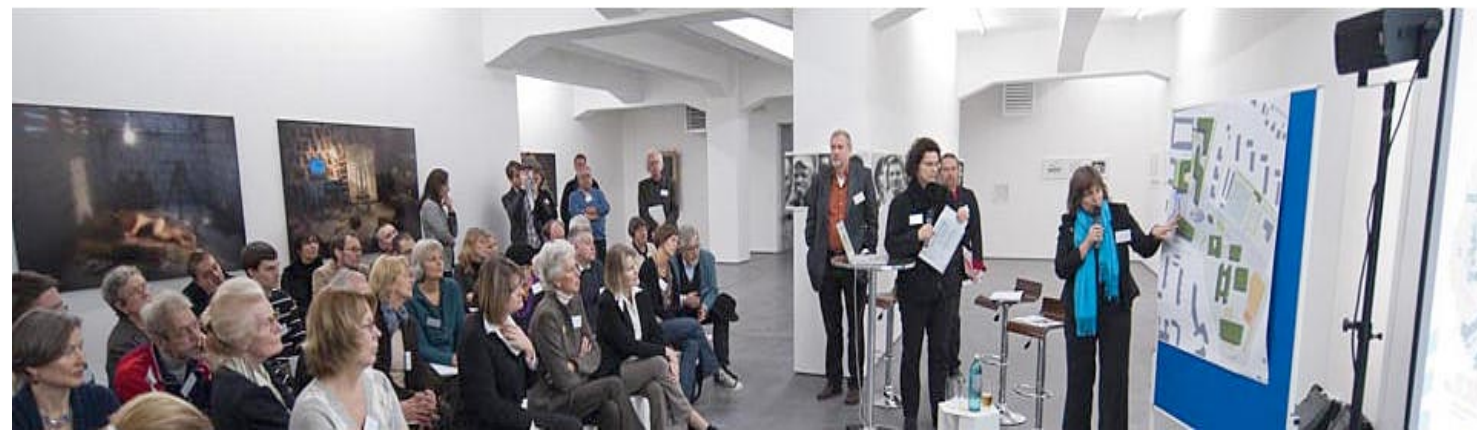

Figure 18: 'Dialogue with Citizens'

\section{Measuring, Monitoring and Evaluating Projects to Determine Best Practices}

As part of the IBA framework, a monitoring and evaluation criteria was established. Kato and Ahren (2007) explain that monitoring results can be used to select best practices, determine if goals and objectives of the project were met, establish pattern-and-process relationships, investigate causality among elements and operate as a mechanism for feedback. Monitoring can inform strategies and better address uncertainty in physical, natural and social systems. 


\section{Combining Formal and Informal Methods}

The IBA Hamburg reaffirms that conventional planning and temporary planning methods do not have to be detached or incompatible. The IBA Hamburg is, in many ways, a conventional model of marketing-led development; while remaining top-down in governance, the IBA remains locally sensitive and participatory-based (Shay, 2012). The thematic focus of the IBA and its treatment of the city as a laboratory has further spawned a renewed understanding of the evolution of cities. Throughout its history, the IBA has encouraged the exploration of new urban development strategies, the incorporation of multiple stakeholders, the practicing of new planning processes, and the testing of new planning procedures. While International Building Exhibits have their roots in Modernism and exist because they "question [...] planning routine and [...] fundamental contemporary conventions regarding the notion of the city", they have essentially been used as a mechanism to discover the 'new city' (IBA Hamburg, 2013, 107). However, the response to the notion of the 'new city' can "only ever be a contemporary one, an assessment of its applicability, its capacity for further development, and its robustness being possible only in interdisciplinary discourse" (IBA Hamburg, 2013, 107). Therefore, the IBA better reflects the currency of our time - it involves research, experimentation and collaboration under a transdisciplinary approach that is relevant to paradigmatic shifts in urban planning, design and development. 


\section{Table 1: Summary of Key Findings and Recommendations}

\begin{tabular}{|c|c|}
\hline $\begin{array}{l}\text { COMMON THEMES AND KEY } \\
\text { OUTCOMES }\end{array}$ & RECOMMENDATIONS FOR PLANNERS \\
\hline $\begin{array}{l}\text { Re-Evaluation of Planning Ideas; } \\
\text { Process-Oriented Planning; } \\
\text { Design-Based Planning } \\
\text { Approaches; } \\
\text { Experimentation }\end{array}$ & $\begin{array}{l}\text { - Recognize planning as a process that occurs over time rather than a desired end-result } \\
\text { - Welcome ephemeral and transitional uses as they engender a sense of ownership, } \\
\text { proprietorship and social investment by citizens } \\
\text { - Implement controlled experiments at an appropriate scale and in a safe-to-fail environment; } \\
\text { be more willing to accept failure and learn from the outcomes of experiments } \\
\text { - Encourage design-based planning approaches including the use of visionary concepts, } \\
\text { design proposals, open-dialogue and small-scale experimentation in combination with } \\
\text { theoretical and empirical methods }\end{array}$ \\
\hline $\begin{array}{l}\text { Encouraging Innovation with } \\
\text { Minimal Resources }\end{array}$ & $\begin{array}{l}\text { - Where warranted, reuse and recycle existing on-site elements to encourage maximum } \\
\text { results with minimal resources } \\
\text { - Recognize that temporary uses can be inexpensively implemented especially when } \\
\text { financial capital is likely to be limited }\end{array}$ \\
\hline Valuing the Temporary & $\begin{array}{l}\text { - Value the incomplete, the transitory, the ephemeral and the temporary as important parts } \\
\text { of the cityscape } \\
\text { - Recognize that transitional uses can be legitimate and powerful tools during uncertain and } \\
\text { indeterminate times as a means for process-oriented and incremental change }\end{array}$ \\
\hline $\begin{array}{l}\text { Flexible Strategies and Approaches } \\
\text { to Development }\end{array}$ & $\begin{array}{l}\text { - Re-evaluate existing regulations, power structures and planning laws that refute temporary } \\
\text { uses } \\
\text { - Critically examine formal planning procedures and practices; where warranted, de- } \\
\text { formalize them to make them more adaptive to changing conditions } \\
\text { - Leave areas 'loosely' defined and provide less programming; encourage citizens to adapt, } \\
\text { claim and use these spaces in a way that is relevant and meaningful to them }\end{array}$ \\
\hline Paradigmatic Shifts & $\begin{array}{l}\text { - Recognize and acknowledge the potential of temporary uses in addressing contemporary } \\
\text { issues and paradigmatic shifts in the urban environment. } \\
\text { - Allow temporary uses to inform and shape the redevelopment and regeneration of the Port } \\
\text { Lands over time }\end{array}$ \\
\hline Support of Key Agents & $\begin{array}{l}\text { - Play a proactive and facilitative role; Use networking, marketing, promotional and financial } \\
\text { tools to provoke public interest and support temporary initiatives } \\
\text { - Create a database to link sites with appropriate temporary users and uses } \\
\text { - Provide expertise, guidance and advice to temporary users } \\
\text { - Commission an intermediary body to provide this expertise and manage temporary } \\
\text { projects if it can not be done by the public authorities or planners }\end{array}$ \\
\hline $\begin{array}{l}\text { Inclusion of Multiple Publics + } \\
\text { Transdisciplinary Approaches }\end{array}$ & $\begin{array}{l}\text { - Ensure professionals, academic and non-academic stakeholders, and community groups } \\
\text { are involved planning decisions } \\
\text { - Strive to include multiple publics through forums and workshops; Use appropriate mediums } \\
\text { and venues relevant to participants } \\
\text { - Understand that the lived experience is more important than physical form in defining a city }\end{array}$ \\
\hline Temporary Use Project Criteria & $\begin{array}{l}\text { - Establish a project criteria to ensure temporary uses support the objectives established for } \\
\text { the Port Lands }\end{array}$ \\
\hline $\begin{array}{l}\text { Measuring, Monitoring \& Evaluating } \\
\text { Projects to Determine Best } \\
\text { Practices }\end{array}$ & $\begin{array}{l}\text { - Use temporary uses to test hypotheses, select best-practices, establish pattern-and- } \\
\text { process relations and investigate causality among elements } \\
\text { - Create evaluation indicators to measure progress and document both the success and } \\
\text { failures associated with a project in order to learn from outcomes } \\
\text { - Acknowledge the potential to fail as an opportunity to learn } \\
\text { - Recognize that decisions must be learned collaboratively }\end{array}$ \\
\hline $\begin{array}{l}\text { Combine Formal and Informal } \\
\text { Methods }\end{array}$ & $\begin{array}{l}\text { - Formalize the informal - analyze and understand the role of temporary uses and the lived } \\
\text { experience; Develop models, tools and prototypes based on this prior analysis, and } \\
\text { formalize these tools to make them available to other people and circumstances } \\
\text { - Critically examine formal procedures and, where appropriate, de-formalize them to make } \\
\text { them more adaptive to changing conditions and informal approaches }\end{array}$ \\
\hline
\end{tabular}




\section{Chapter 6: Recommendations}

It is clear that the problems being experienced in the Port Lands are not unique. Rather, cities around the world are faced with the similar task of remaking and revitalizing their waterfronts over long periods of time and under complex regulatory frameworks with financial uncertainty. The Toronto Port Lands is an example of a postindustrial space in transition. While the Port Lands present a unique and unprecedented development opportunity for the city to advance its status as a dynamic global metropolis, the site can accept little new construction until properly remediated. Current planning frameworks, which estimate a thirty-year planning and implementation timeline, have left the Port Lands in a curious and indeterminate state. With fallow time in excess, there is an opportunity to explore transitional uses and temporary interventions to better optimize the use of this significant spatial resource over the next thirty years. Planners have increasingly come to realize that traditional planning processes do not provide solutions to 'wicked problems' and have since recognized that a homogenous worldview simply does not exist. Although the times we live in are uncertain, planners have come to recognize and acknowledge the certainty of uncertain times and have attempted to adapt planning processes accordingly. Planners are more aware of changing conditions, conflicting sources of information, the prevalence of multiple publics, and the complex and unpredictable processes embedded within society. As a result, planning and design

processes have become less prescriptive and open to a diversity of perspectives and opinions. In order for planners to better validate multiple voices and opinions and encourage an inclusive and progressive planning process, they must recognize the importance of ephemeral and transitional uses and the thirty-year development trajectory for the Port Lands has opened a window for such ephemerality, transitional use, and designed experimentation. There is no need to rely on long-term plans for the space; such product-oriented thinking fails to consider the city as an "ever-changing but essentially temporal phenomenon” (Bishop \& Williams, 2012, 220).

\section{Recognition of Planning as a Process}

While planning for landscapes such as the Port Lands, planners must always consider changing circumstances and potential opportunities. The Port Lands must be recognized as a space in transition where new patterns, perceptions and values will 
emerge, change and evolve. Classical planning is based on the ideas of linearity, permanence, prediction, order and control (Bishop \& Williams, 2012). However, conventional planning paradigms are incoherent in a world of constant change and planners have come to realize this. Therefore, a re-calibration of our ideas to the currency of our time is timely and relevant. Planning must be thought of as a process that occurs over time rather than a desired end-result. As Oswalt et al. (2007) explain, planning must be thought of as an incremental process where the aim is to "define a spatial framework that can absorb different forms of [...] users over time, which cannot be foreseen and should not be defined from the very beginning $[\ldots]$ but which would unfold" (Oswalt et al., 2007, 286). To this end, planning is the successive concentration of applicable and contemporary activities, programs and experiences relative to the currency of time.

\section{Planning Decisions are Collaboratively Learned}

Conceptually, planners must welcome ephemeral and transitional uses because they engender a sense of ownership, proprietorship and social investment by multiple publics; as we move towards a more pluralistic society, transitional uses and ephemerality serve as mechanisms that delegate power to citizens and communities and encourage civic pride, innovation and social responsibility (Bishop \& Williams, 2012). In practice, ephemeral and transitional uses, similar to adaptive management and design, can test hypotheses and can be used to select best practices, establish pattern-andprocess relations and investigate causality among elements (Kato \& Ahren, 2007). Planners must also accept and acknowledge the potential to fail as an opportunity to learn. As explain by Kato and Ahren (2007), "uncertainty is fundamental in [...] planning and needs to be understood in a matter than can inform strategies to address it" (556). It is only in a safe-to-fail environment (Lister, 1998, 2010) where decisions are collaboratively and consciously learned rather than predetermined by rational choice, that planners can capture knowledge and formalize it to inform behaviour, action and decision-making and embrace uncertainty and manage adaptively (Lister, 1998, 2010; Kato and Ahren, 2007). 


\section{Re-Evaluation of Existing Planning Regulations}

Currently, Toronto has few tools that allow for temporary use. For example, zoning, building codes (which to some extent must remain somewhat inflexible), masterplans and land use plans are relatively inflexible instruments used to manage and regulate growth and development (Blumner, 2006). Existing regulations, power structures and planning laws that refute temporary uses must be questioned, reevaluated and revised. Oswalt et al. (2007) argue that the reformation of rigid regulations can make a space, which would otherwise be frozen for a long period of time, available. For example, in the Netherlands, laws limit the amount of control an owner has over his site; if a site or building remains vacant for an extended amount of time, third parties are legally able to occupy the site. In the Port Lands, city planning should leave areas 'loosely' defined and provide less programming (Tito, 2011) or create zones of tolerance where regulations are more permissive. Likewise, planning should also provide opportunities for multifunctional programming leaving areas reserved for temporary activities and open to future initiatives. This will allow for planning to be more responsive to local conditions and changing circumstances.

\section{Support of Key Agents}

Temporary uses and users need the support of key agents, such as municipal authorities and planners, who have access to resources or have applicable skills. The case studies have shown that key agents can play a proactive, supportive and facilitative role. SDAN and the IBA, for example, used networking, marketing, promotional, and financial (subsidization) techniques to provoke public interest and support temporary initiatives. The City of Toronto and Waterfront Toronto should consider these techniques to encourage residents of Toronto to visit and explore the area, and play a more active role in the shaping of the Port Lands. Similarly, a database made available through the municipality, or through an intermediary organization commissioned by the public sector, should be created to link potential sites with appropriate users. An intermediary organization, similar to STEALTH or Renew, could be established to provide expertise and advice to temporary users, property owners and other relevant groups. 


\section{Flexible and Thoughtful Project Criteria}

Flexible contracts, like the ones created by Renew Australia, project criteria standards, such as those created by the IBA, and evaluation indicators to measure progress should be conceived to ensure that temporary uses support the objectives established for the Port Lands and contribute to its vitality. Similarly, one of the strongest aspects, relevant to all three of the cases examined, was the thoughtful criteria created and used to select appropriate temporary users and projects and to indicate project success. The establishment of such criteria allowed the objectives and benefits of each project to be easily measured and monitored. Waterfront Toronto should therefore establish a criteria or framework to ensure temporary users and temporary projects appropriately align with overarching project goals and objectives.

\section{Measuring and Monitoring Outcomes}

As Greenberg (1996) explains, experimentation and small-scale intervention provide an opportunity for informal and collaborative learning where "the failures [of an experiment] are often as informative as the outright successes" (217). Monitoring is therefore an especially relevant and vital tool. Planners, designers, city authorities and temporary users must document both the successes and failures of a project in order to create an environment where results and decisions are learned rather than predetermined by rational choice (Lister, 2010). Planners must also be more willing to accept failure. Often times, planners are expected to understand outcomes and risks involved in planning actions but are forced to wait for data to support their actions out of fear of failure and liability. Therefore, controlled experiments at an appropriate scale and in a safe-to-fail environment, where uncertainties are controlled, allows for continuous, responsive and responsible learning (Lister, 1998, 2000, 2014; Kato \& Ahren, 2007).

\section{Recognition of Planning as a Transdisciplinary Approach}

Urban planning and development is a transdisciplinary process that involves many stakeholders. Similarly, ephemeral and transitional uses require the amalgamation of multiple perspectives. Many conventional planning practices fail to provide residents with some degree of shaping power over the processes of urbanization. Planning is an all-encompassing activity and the making of planning decisions necessitates a transdisciplinary approach with professional, academic and non-academic stakeholders. 
Therefore, planners must strive to include multiple publics in the creation and shaping of the city. The IBA, for example, encouraged the active involvement of all socio-economic and migrant groups through a series of forums and workshops provided for in a variety of languages to ensure the inclusion of a wide spectrum of diverse interests and individuals (Oswalt et al., 2007).

\section{Recognition of the Importance of the Lived Experience}

The city is a human and social product and the lived experience is more important than physical form in defining any city. In order to plan and design in the Port Lands, there must be an understanding of the life that takes place there. Planners must consider how the Port Lands will change and how the appreciation of the area might evolve during its thirty-year trajectory. This involves observing how the space is used while engaging people in the planning and design process at the community-level (Tito, 2011). Planning and design processes, if receptive to multiple perspectives and responsive to local conditions, can serve as powerful vehicles for shared and collaborative learning and active stewardship by citizens (Tito, 2011; Lister, 2007). The planning and design of the Port Lands must take a more design-based approach. Here, visionary concepts and design proposals are crafted following discourse and opendialogue, multidisciplinary research, community engagement, and small-scale experimentation. In all cases, planners and designers must learn to better appreciate spaces in transition and harness the opportunities that exist therein. Simply speaking, planners and design professionals must recognize and acknowledge the potential of temporary uses to address contemporary issues and paradigmatic shifts in the urban environment. Loose space serves as an outlet for diversity, greater self-governance and creative expressiveness and the application of transitional and ephemeral uses in loose space allows citizens to actively engage with and experience space in a way that is relevant to them. Recognizing the importance of the lived experience can better inform and shape the processes of redevelopment and regeneration of the Port Lands over time.

\section{Combination of Formal and Informal Planning Approaches}

Transitional use planning and long-term planning do not need to be treated as mutually exclusive approaches to the design and development of cities. A successful 
and healthy city is one that is able to reimagine and reinvent itself many times over as conditions change (Hume, 2014); this reality nevertheless involves a combination of topdown and bottom-up methods. While innovation frequently evolves in informal contexts, formal contexts ensure long-lasting and sustainable effects; it is therefore necessary to integrate the two more effectively (Oswalt et al., 2007). This means, to a certain degree, formalizing the informal and involves both analyzing and understanding the role of temporary uses and lived experience, developing models, tools and prototypes based on this prior analysis, and formalizing these tools to make them available to other people and circumstances. Likewise, formal procedures and practices of planning must be critically examined and, where appropriate, deformalized to make them more adaptive to changing conditions and informal approaches.

Cities can benefit from planning that values the incomplete, the transitory, the ephemeral and the temporary as important parts of the cityscape; transitional uses and interim phases of development can be legitimate and powerful tools during uncertain and indeterminate times as a means for process-oriented and incremental change. If planners hope to validate multiple voices and opinions in the planning process, they must recognize the importance and legitimacy of ephemerality. 


\section{Appendix A: Case Study Selection Matrix}

\begin{tabular}{|c|c|c|}
\hline & LONDON ROYAL DOCKS & MELBOURNE DOCKLANDS \\
\hline $\begin{array}{l}\text { Location + Physical + } \\
\text { Climatic Conditions }\end{array}$ & $\begin{array}{l}\text { - } \quad \text { London, United Kingdom } \\
\text { - } \quad \text { Northern Hemisphere with marine climate }\end{array}$ & $\begin{array}{l}\text { - } \quad \text { Melbourne, Victoria Harbour, Australia } \\
\text { - Southern Hemisphere with moderate } \\
\text { oceanic/temperate climate }\end{array}$ \\
\hline City Size & $\begin{array}{l}\text { - Region: } 1,572.00 \mathrm{sq} \mathrm{km} \text {; Urban: } 1,737.9 \mathrm{sq} \mathrm{km} \text {; } \\
\text { Metro: } 8,382.00 \mathrm{sq} . \mathrm{km}\end{array}$ & - $\quad 9,990.5 \mathrm{sq} \mathrm{km}$ \\
\hline $\begin{array}{l}\text { Political/Economic } \\
\text { Considerations }\end{array}$ & - Monarchy & $\begin{array}{l}\text { Split between the government of Victoria (state } \\
\text { government) and local government; where local } \\
\text { Councils provide functions such as urban planning }\end{array}$ \\
\hline $\begin{array}{l}\text { Social/Cultural } \\
\text { Considerations }\end{array}$ & - $\quad \mathrm{N} / \mathrm{A}$ & $\begin{array}{l}\text { - Minimal public housing and demand for rental } \\
\text { housing }\end{array}$ \\
\hline $\begin{array}{l}\text { Port Size, State, \& } \\
\text { Contamination }\end{array}$ & $\begin{array}{l}\text { - } \quad \text { Over } 500 \text { hectares (150 ha public ownership) } \\
\text { - } \quad \text { development } \\
\text { - } \quad \text { Port itself is derelict } \\
\text { - } \quad \text { Contamination likely; not so significant as to } \\
\text { preclude redevelopment }\end{array}$ & $\begin{array}{l}\text { - } \quad \text { Project area } 190 \text { ha, including } 44 \text { ha of water } \\
\text { Derelict similar to other post-industrial waterfronts. } \\
\text { Former sheds and wharves could not } \\
\text { accommodate large shipping containers }\end{array}$ \\
\hline Long-Term Vision for Port & $\begin{array}{l}\text { Renewal and redevelopment of former port; to } \\
\text { develop the Royal Docks as a business, hotel, } \\
\text { conferencing, research and logistics district to } \\
\text { support the central London Economy }\end{array}$ & $\begin{array}{l}\text { - } 25 \text { year development trajectory } \\
\text { Renewal and redevelopment project of former } \\
\text { port; goal to offer a mix of uses, including } \\
\text { residential, commercial, retail, dining, leisure and } \\
\text { to extend Melbourne's CBD }\end{array}$ \\
\hline Challenges & $\begin{array}{l}\text { - Area has repeatedly failed to establish itself as an } \\
\text { economic area and a key development industry } \\
\text { Area had seen } 70 \text { master-plans/strategies } \\
\text { developed over a 30-year period - all of which } \\
\text { were unsuccessful. } \\
\text { Individual investments established the London } \\
\text { International Convention Centre (EXCEL), London } \\
\text { City Airport and the University of East London but } \\
\text { were accompanied by residential developments of } \\
\text { mediocre architectural quality. }\end{array}$ & $\begin{array}{l}\text { Inner-city living becoming more popular; } \\
\text { increasing population places pressure on city to } \\
\text { provide housing and commercial spaces }\end{array}$ \\
\hline $\begin{array}{l}\text { Purpose of Temporary } \\
\text { Intervention \& Objective }\end{array}$ & $\begin{array}{l}\text { - Sites considered for long-term development but } \\
\text { had potential for short-term economic activity were } \\
\text { utilized. } \\
\text { Competition to find entrepreneurial activities that } \\
\text { would create jobs and reflects long-term visions. } \\
\text { Winning proposals had to be innovative, reflective } \\
\text { of objectives, and capable of being transferred to } \\
\text { other sites in the locality (+ Property Week) }\end{array}$ & \multirow{2}{*}{$\begin{array}{l}\text { - } \quad \text { Creation of the Docklands Authority to establish } \\
\text { and transform the disused port and rail area into a } \\
\text { modern urban waterfront. } \\
\text { Governance shared between the City of } \\
\text { Melbourne and Places Victoria } \\
\text { - } \quad \text { Partnership between Renew Australia, City of } \\
\text { Melbourne, MAB Corporation, Places Victoria } \\
\text { Renew Australia, commissioned by the City of } \\
\text { Melbourne, to match vacant spaces with short- } \\
\text { term uses, creative projects and community } \\
\text { initiatives } \\
\text { Renew Australia negotiates with property owners } \\
\text { to license spaces and match them with local } \\
\text { creative enterprises/ groups. They negotiate } \\
\text { participation agreements for temporary projects } \\
\text { and manage short term uses } \\
\text { Users are able to test projects in vacant } \\
\text { properties; if successful, projects can become } \\
\text { permanent }\end{array}$} \\
\hline $\begin{array}{l}\text { Role of Municipality }+ \text { Key } \\
\text { Agents }\end{array}$ & $\begin{array}{l}\text { London Development Agency (+ Municipality) } \\
\text { swept away former master plans and created } \\
\text { strategic framework, planning policy and land } \\
\text { development alliance (to create market confidence } \\
\text { and to establish long-term vision). }\end{array}$ & \\
\hline $\begin{array}{l}\text { Planned vs. Unplanned; } \\
\text { Regulated vs. Unregulated }\end{array}$ & $\begin{array}{l}\text { - Planned, regulated and structured into the long- } \\
\text { term regeneration strategy }\end{array}$ & $\begin{array}{l}\text { Planned and regulated. Temporary users able to } \\
\text { access vacant sites on a rolling } 30 \text {-day basis. } \\
\text { Space is rent-free for users wanting to experiment } \\
\text { or test the viability of projects in a commercial } \\
\text { space. }\end{array}$ \\
\hline
\end{tabular}




\begin{tabular}{|c|c|c|}
\hline & KALASAMATA & KØGE KYST \\
\hline $\begin{array}{l}\text { Location + Physical + } \\
\text { Climatic Conditions }\end{array}$ & $\begin{array}{l}\text { - Helsinki, Finland } \\
\text { - Northern Hemisphere with continental climate }\end{array}$ & $\begin{array}{ll}\text { - } \quad \text { Koge (suburb located south of Copenhagen) } \\
\text { - Northern Hemisphere with oceanic climate }\end{array}$ \\
\hline City Size & - $\quad 715.49 \mathrm{sq} \mathrm{km}$ & $\begin{array}{l}\text { - } 255.47 \mathrm{sq} \mathrm{km}(2014 \text {, the urban area had a } \\
\text { population of } 35,768)\end{array}$ \\
\hline $\begin{array}{l}\text { Political/Economic } \\
\text { Considerations }\end{array}$ & $\begin{array}{l}\text { - Top-down oriented planning and control typically } \\
\text { dictated the development of the city; more public } \\
\text { involvement occurring }\end{array}$ & - $\quad \mathrm{N} / \mathrm{A}$ \\
\hline $\begin{array}{l}\text { Social/Cultural } \\
\text { Considerations }\end{array}$ & $\begin{array}{l}\text { - One of Europe's fastest growing urban } \\
\text { metropolises } \\
\text { - Foreign citizens make up } 8 \% \text { of the population }\end{array}$ & - N/A \\
\hline $\begin{array}{l}\text { Port Size, State, \& } \\
\text { Contamination }\end{array}$ & $\begin{array}{l}\text { - } \quad \text { Some areas active, others derelict } \\
\text { - } \quad \text { Soil remediation necessary although not } \\
\text { significantly contaminated } \\
\text { - } 175 \text { ha }\end{array}$ & $\begin{array}{l}\text { The current port in Koge is an active and dynamic } \\
\text { port, with lots of traffic and further growth } \\
\text { expected in the future. }\end{array}$ \\
\hline Long-Term Vision for Port & $\begin{array}{l}\text { End-product to include: } 6 \text { apartment towers, hotel } \\
\text { and office towers; and a commercial and } \\
\text { recreation centre. The housing types to include } \\
\text { apartment buildings, terraced houses, urban villas, } \\
\text { loft apartments and floating houses } \\
\text { - } 25 \text {-year trajectory } \\
\text { - Planning and construction to be strategic/steered } \\
\text { throughout the construction period to allow the } \\
\text { space to continue to function as a living and } \\
\text { working space }\end{array}$ & \multirow{3}{*}{$\begin{array}{l}\text { - Koge Kyst is suburb south of Copenhagen, which } \\
\text { is actively transforming its harbour. The area } \\
\text { consists of three parts: the Station Area, Sondre } \\
\text { Havn and the Collstrop Site. Urban renewal will } \\
\text { generate new functions and new interrelationships } \\
\text { between the three areas - and with the rest of the } \\
\text { town of Koge. The new part of the town will be } \\
\text { developed over the coming } 20 \text { years. The project } \\
\text { will take place on the basis of an idea competition } \\
\text { for professional players, such as architects and } \\
\text { town planners, who are to provide input for the } \\
\text { development. In addition, citizens, the business } \\
\text { community, retailers and other stakeholders will } \\
\text { be involved in the work, contributing visions, } \\
\text { suggestions and good ideas. The overall vision of } \\
\text { the project is to create a unique, attractive and } \\
\text { sustainable town district. In brief, the } \\
\text { circumstances/conditions of Koge, specifically its } \\
\text { physical and spatial conditions (as a suburb and a } \\
\text { historical town) contrast too starkly from Toronto's } \\
\text { and will therefore not be considered for this } \\
\text { project. }\end{array}$} \\
\hline Challenges & $\begin{array}{l}\text { - Lack of definition since the decommissioning of } \\
\text { the rail and port industries. }\end{array}$ & \\
\hline $\begin{array}{l}\text { Purpose of Temporary } \\
\text { Intervention \& Objective }\end{array}$ & $\begin{array}{l}\text { PART (commissioned by City of Helsinki) called to } \\
\text { curate art exhibits the harbour area and install } \\
\text { temporary projects; sought to provide opportunities } \\
\text { for citizen participation; } \\
\text { Citizens were able to embrace and claim the area; } \\
\text { an unusual sense of freedom being tolerated } \\
\text { Temporary projects/events include: graffiti wall, } \\
\text { container village, green biking lanes, container } \\
\text { cafe, temporary solar kitchen, open-air cinemas, } \\
\text { bike-breakfasts, pizza ovens, festivals, asphalt } \\
\text { paintings, urban gardens, container theatre, public } \\
\text { schools }\end{array}$ & \\
\hline $\begin{array}{l}\text { Role of Municipality + Key } \\
\text { Agents }\end{array}$ & $\begin{array}{l}\text { - City of Helsinki initiated temporary uses, played a } \\
\text { facilitating role, provided a framework for } \\
\text { temporary use projects and authorized PART (an } \\
\text { urban design and architecture office) to curate } \\
\text { temporary exhibits. } \\
\text { - City tolerated and encouraged openness, } \\
\text { imagination, and proprietorship. } \\
\text { City kick-started process by installing } \\
\text { environmental art in former harbour area and set } \\
\text { up shipping containers for artists and community } \\
\text { activities }\end{array}$ & - N/A \\
\hline $\begin{array}{l}\text { Planned vs. Unplanned; } \\
\text { Regulated vs. Unregulated }\end{array}$ & $\begin{array}{l}\text { - Planned and regulated; residents encouraged to } \\
\text { take authorship in the area }\end{array}$ & - N/A \\
\hline
\end{tabular}




\begin{tabular}{|c|c|c|}
\hline & HAMBURG (IBA) & COPENHAGEN HARBOUR - HARBOUR BATHS \\
\hline $\begin{array}{l}\text { Location + Physical + } \\
\text { Climatic Conditions }\end{array}$ & $\begin{array}{l}\text { - Hamburg, Germany - Elbe islands of Wilhelmsburg } \\
\text { (river island) and Veddel, and Harburg Upriver } \\
\text { Port (on the Elbe, the ports of Hamburg and } \\
\text { Harburg) } \\
\text { - Northern Hemisphere with oceanic climate }\end{array}$ & $\begin{array}{ll}\text { - } & \text { Copenhagen Denmark (Islands Brygge) } \\
\text { - } & \text { Northern Hemisphere with oceanic climate }\end{array}$ \\
\hline City Size & - $\quad 755.3 \mathrm{sq} \mathrm{km}$ & - City: $86.20 \mathrm{sq} \mathrm{km}$; Metro $2.778,3 \mathrm{sq} \mathrm{km}$ \\
\hline $\begin{array}{l}\text { Political/Economic } \\
\text { Considerations }\end{array}$ & - $\quad$ State Government & $\begin{array}{l}\text { - } \quad \text { Monarchy } \\
\text { Democracy (with City Hall, Mayor, Council } \\
\text { Members) }\end{array}$ \\
\hline $\begin{array}{l}\text { Social/Cultural/Environment } \\
\text { al Considerations }\end{array}$ & $\begin{array}{l}\text { - Wilhelmsburg in a flood-prone location; vulnerable } \\
\text { topography } \\
\text { Issues of climate change } \\
\text { - The Elbe Islands a key site for infrastructure such } \\
\text { as waste disposal, transportation, and } \\
\text { manufacturing. } \\
\text { - Characterized by lower-cost housing } \\
\text { - Area home to marginalized social groups; history } \\
\text { of cultural polarization; recent estimates put the } \\
\text { number of people with a migrant background at } \\
30 \% \text {; } \\
\text { Prevalence of 'Metrozones' (neglected periphery } \\
\text { space) }\end{array}$ & $\begin{array}{l}\text { - Cultural hub of Denmark } \\
\text { Immigrants from Western countries make up } 8.1 \% \\
\text { of the population; Immigrants and descendants } \\
\text { from non-Western countries make up } 14.6 \%\end{array}$ \\
\hline $\begin{array}{l}\text { Port Size, State, \& } \\
\text { Contamination }\end{array}$ & $\begin{array}{l}\text { - Wilhelmsburg covers } 14 \mathrm{sq} \mathrm{mi} \text { (with low population } \\
\text { density) }\end{array}$ & $\begin{array}{l}\text { - } \quad 2,500 \mathrm{sq} m \text { area for the Baths } \\
\text { - } \quad \text { transfict but harbour undergoing signification } \\
\text { tran }\end{array}$ \\
\hline Long-Term Vision for Port & $\begin{array}{l}\text { - To redevelop the Elbe islands; residential, } \\
\text { commercial space, education establishments, } \\
\text { nurseries, senior citizens homes, sports facilities, } \\
\text { artist space, and green space } \\
\text { To construct a "city of the future" and develop } \\
\text { strategies to the potential of the choked inner city } \\
\text { peripheries; resolve conflict between living and } \\
\text { working areas/harbour and city development }\end{array}$ & \multirow{2}{*}{$\begin{array}{l}\text { - To reclaim the harbour for social and cultural use } \\
\text { (city has had a history of turning its back to the } \\
\text { water) } \\
\text { - Copenhagen' harbour is in the midst of a } \\
\text { transformation from an industrial port and traffic } \\
\text { junction to a cultural and social centre } \\
\text { - To create an accessible and accommodating } \\
\text { environment } \\
\text { - To transform the underused waterfront into an } \\
\text { urban green space (result was Harbour Park and } \\
\text { Harbour Baths - "Transition from Land to Water") }\end{array}$} \\
\hline Challenges & $\begin{array}{l}\text { - Hamburg experiencing growth and return of } \\
\text { population into the city } \\
\text { Elbe Island as a 'Metrozones' offers an opportunity } \\
\text { to accommodate this growth without the need to } \\
\text { sprawl into open land. } \\
\text { - The challenge to appropriately restructure and } \\
\text { redevelop the area without displacing existing } \\
\text { communities. }\end{array}$ & \\
\hline $\begin{array}{l}\text { Purpose of Temporary } \\
\text { Intervention \& Objective }\end{array}$ & $\begin{array}{l}\text { - IBA (International Building Exhibition) (a site and } \\
\text { time specific instrument) initiative; IBA operates as } \\
\text { a government-supported independent agency/a } \\
\text { public limited liability company (commissioned by } \\
\text { the city government when strategies are in need to } \\
\text { mitigate contemporary urban issues). } \\
\text { The IBA is given charge of studying the city to } \\
\text { determine key issues and develop regeneration } \\
\text { strategies } \\
\text { Three themes established by the IBA: (1) Cities } \\
\text { and Climate; (2) Metrozones; (3) Cosmopolis } \\
\text { Goal to improve the potential of the choked inner } \\
\text { city peripheries; resolve conflict between living and } \\
\text { working areas/harbour and city development. }\end{array}$ & $\begin{array}{l}\text { - Harbour Baths have been added along the } \\
\text { waterfront to supplement a lack of beaches inside } \\
\text { the city (The Baths themselves to imitate the } \\
\text { landscape of an actual beach) } \\
\text { In } 2002 \text { the first temporary harbour swimming } \\
\text { baths opened at Islands Brygge. It was so } \\
\text { successful that work soon started on the } \\
\text { development of a permanent harbour swimming } \\
\text { facility } \\
\text { Baths were originally temporary but became } \\
\text { permanent due to widespread public acceptance } \\
\text { Goal of the baths - to extend urban activity into } \\
\text { the waterfront, a connection of water to mainland } \\
\text { - More baths being constructed around the city } \\
\text { (along with winter swimming baths) }\end{array}$ \\
\hline $\begin{array}{l}\text { Role of Municipality }+ \text { Key } \\
\text { Agents }\end{array}$ & $\begin{array}{l}\text { - } \quad \text { IBA called into action by government } \\
\text { - IBA consult with local government, private } \\
\text { developers and public to create a unified }\end{array}$ & - $\quad$ City of Copenhagen, PLOT (BIG/JDS) \\
\hline
\end{tabular}




\begin{tabular}{|c|c|c|}
\hline & $\begin{array}{l}\text { development strategy as well as strategic visions; } \\
\text { IBA advisees local governments, produces soft } \\
\text { instruments for development, and encourages } \\
\text { citizen participation }\end{array}$ & \\
\hline $\begin{array}{l}\text { Planned vs. Unplanned; } \\
\text { Regulated vs. Unregulated }\end{array}$ & $\begin{array}{l}\text { - Planned and regulated, high degree of citizen } \\
\text { participation } \\
\text { - Funding provided for by public, private businesses } \\
\text { and institutions } \\
\text { - } \begin{array}{l}\text { Partnerships, engagement and dialogue key to } \\
\text { success }\end{array}\end{array}$ & $\begin{array}{l}\text { Planned for temporary but became permanent. } \\
\text { More baths being constructed throughout the city } \\
\text { making it possible for residents to swim in the } \\
\text { middle of the city. }\end{array}$ \\
\hline
\end{tabular}




\begin{tabular}{|c|c|c|c|}
\hline & NDSM & $\mathrm{H}+$ & AARHUS \\
\hline $\begin{array}{l}\text { Location + Physical + } \\
\text { Climatic Conditions }\end{array}$ & $\begin{array}{l}\text { - } \quad \text { Amsterdam, The Netherlands } \\
\text { - } \quad \text { Northern Hemisphere with oceanic climate }\end{array}$ & $\begin{array}{ll}\text { - } & \text { Helsingbor, Sweden } \\
\text { Northern Hemisphere } \\
\text { with oceanic climate }\end{array}$ & $\begin{array}{ll}\text { - } & \text { Aarhus, Denmark } \\
\text { Northern } \\
\text { Hemisphere with } \\
\text { oceanic climate }\end{array}$ \\
\hline City Size & $\begin{array}{l}\text { - Dense/Intensely urbanized; } 219.4 \mathrm{sq} \mathrm{km} \text { with } \\
\text { 4,457 inhabitants per sq km }\end{array}$ & - $\quad 1.353 \mathrm{sq} \mathrm{km}$ & $\begin{array}{l}\text { - Urban: } 91 \mathrm{sq} \mathrm{km} \text {; } \\
\text { Municipal: } 468 \mathrm{sq} \\
\mathrm{km}\end{array}$ \\
\hline $\begin{array}{l}\text { Political/Economic } \\
\text { Considerations }\end{array}$ & $\begin{array}{ll}\text { - } & \text { Monarchy } \\
\text { - } & \text { Democracy }\end{array}$ & - N/A & - $\quad \mathrm{N} / \mathrm{A}$ \\
\hline $\begin{array}{l}\text { Social/Cultural/Environment } \\
\text { al Considerations }\end{array}$ & $\begin{array}{l}\text { - Gentrification; reducing the number of affordable } \\
\text { living spaces for the city's informal arts and culture } \\
\text { sector. }\end{array}$ & - $\quad \mathrm{N} / \mathrm{A}$ & - $\quad \mathrm{N} / \mathrm{A}$ \\
\hline $\begin{array}{l}\text { Port Size, State, \& } \\
\text { Contamination }\end{array}$ & $\begin{array}{l}\text { - Derelict due to collapse of shipping building } \\
\text { industry and large areas of contaminated land left } \\
\text { behind } \\
\text { - } 20,000 \text { sq.m shipyard hall in the disused harbour } \\
\text { area of Amsterdam North }\end{array}$ & \multirow{6}{*}{$\begin{array}{l}\text { - Both of these cities are } \\
\text { waterfront revitalizatior } \\
\text { particular focus on gre } \\
\text { The extent of the work } \\
\mathrm{H}+\text { is the largest urban } \\
\text { Helsingbor; likewise } \mathrm{M} \\
\text { Urban Transformation } \\
\text { Aarhus. } \\
\text { Both examples will see } \\
\text { renewal of their respec } \\
\text { both cases, the cities } \\
\text { with the rest of the city } \\
\text { neighbourhoods. } \\
\text { Similar long-term objec } \\
\text { connectivity, provide re } \\
\text { uses and implement sc } \\
\text { sustainable solutions. } \\
\text { However, for the purpo } \\
\text { project, information wa } \\
\text { due to language barrie } \\
\text { new for conclusive res } \\
\text { research could explore } \\
\text { implementation of stra }\end{array}$} & $\begin{array}{l}\text { undergoing significant } \\
\text { projects, each with a } \\
\text { infrastructural solutions. } \\
\text { both cases is ambitious. } \\
\text { enewal project to date in }\end{array}$ \\
\hline Long-Term Vision for Port & $\begin{array}{l}\text { - Long-term regeneration goals; area planned as a } \\
\text { neighbourhood }\end{array}$ & & roject is the largest in \\
\hline Challenges & $\begin{array}{l}\text { - Space was long neglected following the collapse of } \\
\text { the shipping industry } \\
\text { The vacuum left by the collapse was filled by } \\
\text { artists and squatters; the space become a venue } \\
\text { for parties and events (not endorsed by the } \\
\text { municipality who still had to cover the costs of the } \\
\text { maintenance of the area and its buildings) }\end{array}$ & & $\begin{array}{l}\text { ve to link the waterfront } \\
\text { ind surrounding } \\
\text { ves include: to increase } \\
\text { idential and commercial } \\
\text { ially and environmentally }\end{array}$ \\
\hline $\begin{array}{l}\text { Purpose of Temporary } \\
\text { Intervention \& Objective }\end{array}$ & $\begin{array}{l}\text { - An open competition for ideas launched by the } \\
\text { Municipality of Amsterdam North } \\
\text { Purpose was to re-establish a degree of control } \\
\text { over the area, and at the same time bring forward } \\
\text { new jobs and regeneration } \\
\text { - Open competition won my Kinetisch Noord who } \\
\text { divide the hall into thematic zones; spaces within } \\
\text { the hall were filled by creative commercial } \\
\text { ventures, artists, youth }\end{array}$ & & $\begin{array}{l}\text { es of this research } \\
\text { either difficult to obtain } \\
\text { or the project was too } \\
\text { arch. However, further } \\
\text { hese projects and their } \\
\text { gic "test-bed" projects. }\end{array}$ \\
\hline $\begin{array}{l}\text { Role of Municipality + Key } \\
\text { Agents }\end{array}$ & $\begin{array}{l}\text { - Amsterdam North to provided a ferry to link the } \\
\text { space to the central area; } \\
\text { Council renovated the former wharf canteen to } \\
\text { provide a restaurant and office space to put the } \\
\text { area on the map } \\
\text { - } \\
\text { Amsterdam North introduced temporary student } \\
\text { housing in a development of shipping containers } \\
\text { SDAN commissioned STEALTH.unlimitied to } \\
\text { prepare a strategy for the application of temporary } \\
\text { uses in the area to meet long-term visions }\end{array}$ & & \\
\hline $\begin{array}{l}\text { Planned vs. Unplanned; } \\
\text { Regulated vs. Unregulated }\end{array}$ & - $\quad$ Planned and regulated & & \\
\hline
\end{tabular}


Appendix B: What Makes a Good Dockland Spaces Project?

\section{What Makes a Good Dockland Spaces Project?}

1. It adds life to the area - This opportunity is intended to draw out and support creative people with the ideas, initiative, energy and potential to contribute to the life of the local community. Docklands Spaces will favour projects most likely to add different layers of interest and activity (especially in high visibility retail spaces), and attract new visitors to the precinct. Activation of otherwise empty spaces should encourage longer-term commercial opportunities for surrounding businesses.

2. It is unique - Docklands Spaces is not about replicating other shops, or filling every space with the same type of business. This pilot project seeks to provide the growing community with a range of cultural and creative opportunities. Projects that showcase people making and presenting original work are ideal.

3. It has a high degree of professionalism or a very clear idea - There are only a limited number of spaces available so Renew Australia will prioritize applications from individuals and enterprises that are serious about what they are doing and have a very clear idea of what they are trying to achieve. A shop-front (or office space) may not be the best place to start a new creative practice or business idea without relevant experience or a proven market; Docklands Spaces is most suitable for those enterprises trying to take what they are already doing to another level.

4. It is ongoing but temporary - Docklands Spaces is seeking projects that will make ongoing uses of the spaces for a minimum of 30 days. Renew Australia does not have the capacity to support creative enterprises to access space for single exhibitions or infrequent uses.

5. It is ready - Taking on a shop-front or opening an office or studio can be a major commitment. Docklands Spaces is keen to support enterprises that are ready to take that step up and can demonstrate their commitment based on previous experience. Ideally, selected projects will have the capacity to move in and start making use of the space soon after their proposals are approved.

Source: Dockland Spaces, 2012 
Appendix C: The IBA Excellence Criteria

IBA Excellence - The Seven Criteria:

1. Distinctiveness

The project must be characterized by distinctiveness and originality; it must embody innovation and qualitatively distinguish itself from other "normal" projects.

\section{IBA specificity}

The project must be such that it would be difficult or impossible to realize without IBA support. It should not only be tailored to the topics dealt with by IBA; it must go a step further and "need" to IBA as an instrument.

\section{All-roundedness}

The project should incorporate several if the IBA's leitmotifs or at least comply with their diverse demands; it must also be an "all-rounder".

\section{Structural effectiveness}

The project must make a sustainable contribution to the structural improvement of the residential, employment and leisure situation in the IBA area and should be able to hold its own within an urban economic valuation.

\section{Process capability}

The project should encourage the largest possible circle of people to participate, should be adaptable to changing circumstances and be realizable in stages.

\section{Presentation suitability}

The project must be presentable. Not only as built volume; also as contribution to the solution of questions, which arise within the context of the IBA leitmotifs, whereby the potential it holds for new experience is also important.

\section{Feasibility}

The project must be realizable by 2013 ; or as the case may be, the conditions of realization must be fulfilled - from the legal, financial and technical points of view.

Source: IBA Hamburg, 2012a 


\section{Appendix D: IBA Projects by Theme}

\section{CITIES + CLIMATE CHANGE}

1. Elbe Islands Dyke Park: Experiencing the Island Landscape

2. Energy Hill Georgswerder: Hill of new horizons

3. Hamburg Energy Partnerships: The household as an energy laboratory

4. InnovationCampus - Green Technologies: A centre for science and research

5. Jenfelder Au: Revitalisation of the former Lettow-Vorbeck Barracks

6. New Port Railway Building on Spreehafen Island: Hamburgís first office building constructed to a passive house standard

7. Pilot Project Kreetsand: Creating flood plains and making the tidal Elbe experience possible

8. Top Climate Plan: A step in the direction towards CO2-neutral energy supply to the Elbe Islands

9. Top Climate Plan - Neuenfelder Strafle 107: A step in the direction towards CO2-neutral energy supply to the Elbe Islands

10. Top Climate Plan - Wilhelmsburger Strafle 76-82:

11. A step in the direction towards $\mathrm{CO} 2$-neutral energy supply to the Elbe Islands

12. Wilhelmsburg Cycle City: Wilhelmsburg on its Way to Becoming a Model District for Forwardlooking Cycling

13. Energy Bunker: A memorial drives the district

14. Geothermal Energy Wilhelmsburg: Potential underground

15. IBA DOCK: The metropolis moves onto water

16. Integrated Energy Network Wilhelmsburg Central: A virtual power station - in the network of synergies

17. Low-Energy Housing in Haulander Weg: Living in a good atmosphere

18. Open House: Flexible dwelling forms on the Ernst-August-Kanal

19. ëRenewable Wilhelmsburgí Climate Protection Concept: Projects as models for climate-friendly urban development

20. Top Climate Plan - ëAuf der H^heí: A step in the direction towards CO2-neutral energy supply to the Elbe Islands

21. Top Climate Plan - Pontoon Park Gangway: A step in the direction towards CO2-neutral energy supply to the Elbe Islands

22. VELUX Model Home 2020: LightActive House: Inventory of innovation

\section{METROZONES}

1. A Picture of the Future in Georgswerder: Steer future changes within the district

2. BIQ: Smart Material Houses

3. Creating a bridge to Harburgís Schloflinsel: New routes to the Harburg Schloflinsel

4. Entrance complex to the Inselpark: A lively mixture for the centre

5. Georg-Wilhelm-Courtyards: Inexpensive, family-friendly working and living quarters

6. Harburg Inland Port: The leap across the Elbe Islands lands here

7. Housing on the Hafencampus: New Housing on old harbour sites

8. Hybrid House: Hybrid Houses

9. igs Centre: Hybrid Houses

10. Island Park Hall: Entrance complex to the Inselpark

11. Maritime Housing by the Kaufhaus Kanal:nLiving and working with port flair 
12. New Building of the State Ministry for Urban Development and the Environment: A lively mixture for the centre

13. Opening of the Spreehafen: The port as a free space for the district

14. Recreation in the Harbour: Spreehafen ñ a site for many acitvitites

15. Senior Citizen Centre on Inselpark: Entrance complex to the Inselpark

16. Smart Material Houses: Smart building materials for the future

17. Soft House: Smart Material Houses

18. WaterHouses - Living at Inselpark: Sustainable construction with and on water

19. WOODCUBE: Smart Material Houses

20. Basic building and do-it-yourself builders: Smart Price Houses

21. Ferries for Wilhelmsburg: New connections on the Elbe Island

22. Harbour launch connections and expansion of the canoeing route: Wilhelmsburg waterborne

23. Harburger Schloflinsel Park: New free space qualities on Harburg Schloflinsel

24. Hybrid Development: Hybrid Houses

25. Hybrid Houses: Houses that adapt to the wishes of their residents

26. InselAkademie Building: Entrance complex to the Inselpark

27. Marina on the ëSchloflinselí: Living in the Harburg Dock

28. Medical centre and health academy: Entrance complex to the Inselpark

29. New Routes around the Spreehafen: Discover the Spreehafen

30. Park Quarter: Living in a unique location

31. Schellerdamm Student Residence: A student residence at Harburg upriver port

32. Smart is green: Smart Material Houses

33. Smart Price Houses: Houses built in a beautiful, inexpensive way

34. The Building Exhibition within the Building Exhibition: IBA shows the future of building

35. Wilhelmsburg Central: From the inner city margin to the new centre

36. Wood 5 1/4: Entrance complex to the Inselpark

37. W $f$ LDERHAUS: Entrance complex to the Inselpark

\section{COSMOPOLIS}

1. AWIS: Elbe Islands Agency for Business and Schools

2. Centre of Language and Excercise: Learning in motion

3. Education Drive: Safeguarding the future in the learning metropolis

4. Elbe Islands Creative Quarter: Arts Platform

5. Elbe Islands Creative Quarter: Spaces for the Art

6. Elbe Islands Creative Quarter: Creativity meets City

7. Global Neighbourhood: Reconstruction of a Residential Quarter

8. Global Neighbourhood - Weimarer Platz with Pavilion: The New Heart of the Weltquartier

9. House of Projects: New job opportunities in boat building

10. Learning by Doing: Education Centre St, benhofer Weg

11. MultiCooltiPark: Children and Adolescence shape their quarter

12. New Hamburg Terraces: Urban Living at the Garden Exhibition

13. University of Neighbourhoods: Temporary architecture for the learning city

14. Bakery: A Bakery for Johanna

15. Education Centre St, benhofer Weg: Learning by Doing

16. Elbe Islands Creative Quarter: Cultural Diversity Projects

17. Elbe Islands Creative Quarter: Art Creates Work

18. Elbe Islands Creative Quarter: LABORatory for Art and Urban Development

19. Gateway to the World Educational Centre: Education for the whole quarter 
20. Global Neighbourhood - building modernisation, designing of open areas, new housing construction: The Global Neighbourhood is taking shape

21. Global Neighbourhood - World Commercial Park: A Place to Work not far from Home for Local Companies and Founders of New Businesses

22. Intercultural Public Spaces: Equal rights for everybody

23. MEDIA DOCK: Media home made - numerous opportunities under one roof

24. Multipurpose Circuit: New tracks on the Elbe Islands - on foot, on rollers or on wheels

25. Rotenhauser Feld: Public Space for the Intercultural Neighbourhood

26. Veringeck: Growing older in a shared community

Source: IBA Hamburg, IBA, 2012c 


\section{References}

Abbott, J. (2005). Understanding and Managing the Unknown: The Nature of Uncertainty in Planning. Journal of Planning Education and Research, 24(3), 237-251. http://doi.org/10.1177/0739456X04267710

Arlt, P. (2006). Urban Planning and Interim Use. In F. Haydn \& R. Temel (Eds.), Temporary urban spaces: concepts for the use of city spaces (pp. 39-46). Basel: Birkhäuser.

Bengs, C., Hentilä, H. L., \& Nagy, D. (2002). Urban Catalysts: Strategies for Temporary Uses-Potential for Development of Urban Residual Areas in European Metropolises. Espoo: Centre for Urban and Regional Studies Helsinki University of Technology.

Berg, B. L. (2012). Qualitative research methods for the social sciences (8th ed). Boston: Pearson.

Blumner, N. (2006). Planning for the Unplanned: Tools and Techniques for Interim Use in Germany and the United States. Deutsches Institut Für Urbanistik, Occasional Papers. Retrieved from http://www.difu.de/english/occasional/

Brassley, P. (1998). On the unrecognized significance of the ephemeral landscape. Landscape Research, 23(2), 119-132. doi:10.1080/01426399808706531

City of Toronto, City Planning. (2013). Port Lands Profile. Toronto: City of Toronto. Retrieved from http://www.portlandsconsultation.ca/sites/all/themes/portlands/files/Port\%20Profil e\%20nov12.pdf

Corner, J. (1999). The Agency of Mapping: Speculation, Critique and Invention. In D. E. Cosgrove (Ed.), Mappings (pp. 213-297). London: Reaktion Books. Retrieved from http://www.cfa.arizona.edu/ahgsa/files/ahgsa/Corner_Agency-of-Mapping1.pdf

Crawford, M. (2012). Introduction, Preface: The Current State of Everyday Urbanism and Blurring the Boundaries: Public Space and Private Life. In M. Larice \& E. Macdonald (Eds.), The urban design reader (Second edition, pp. 344-357). New York: Routledge.

Dockland News. (2014, March 6). Gehl report finally emerges. Dockland News. Melbourne. Retrieved from http://www.docklandsnews.com.au/editions/article/gehl-report-finallyemerges_9527I

Dockland Spaces. (2012). Dockland spaces: About. Retrieved February/05, 2015, from http://docklandsspaces.org/about 
Edensor, T. (2006). Social Practices, Sensual Excess and Aesthetic Transgression in Industrial Ruins. In K. A. Franck \& Q. Stevens (Eds.), Loose space: possibility and diversity in urban life (pp. 234-252). New York: Routledge.

Esfahani, A. H. (2013). Exploring People-Centred Development in Melbourne Docklands Redevelopment: Beyond Physical Development and Collaborative Planning (Master of Urban Studies). Simon Fraser University, British Columbia.

Fabian, L., \& Samson, K. (2014). DIY Urban Design: Between Lucid Tactics and Strategic Planning. In B. T. Knudsen, D. R. Christensen, \& P. Blenker (Eds.), Enterprising Initiatives in the Experience Economy, Transforming Social Worlds (1st ed., p. 39). New York: Routledge.

Fernando, N. A. (2006). Open-Ended Space: Urban Streets in Different Cultural Contexts. In K. A. Franck \& Q. Stevens (Eds.), Loose space: possibility and diversity in urban life (pp. 54-72). New York: Routledge.

Fincher, R., \& Iveson, K. (2008). Introduction; conceptualizing redistribution in planning; planning for redistribution in practice. Planning and diversity in the city (pp. 1-48). Houndmills, Basingstoke, Hampshire: Palgrave Macmillan.

Finn, D. (2014). DIY urbanism: Implications for cities. Journal of Urbanism: International Research on Placemaking and Urban Sustainability, 7(2-19) doi:10.1080/17549175.2014.891149

Franck, K. A., \& Stevens, Q. (Eds.). (2006). Loose space: possibility and diversity in urban life. New York: Routledge.

Greenberg, K. (1996). Toronto: The Urban Waterfront as a Terrain of Availability. In P. Malone (Ed.), City, capital, and water (pp. 195-218). London; New York: Routledge.

Harvey, D. (2008). The Right to the City. New Left Review, 53. Retrieved from http://davidharvey.org/media/righttothecity.pdf

Haydn, F., \& Temel, R. (2006). Temporary urban spaces: concepts for the use of city spaces. Basel: Birkhäuser.

Hentilä, H-L. (2003). Central Micro-Peripheries: Temporary uses of Central Residual Spaces as Urban Development Catalysts. In Peripheries, Centres, and Spatial Development in the New Europe. Jyväskylä. Retrieved from https://ideas.repec.org/p/wiw/wiwrsa/ersa03p242.html

Hume, C. (2014, May 30). Temporary Toronto's lasting results. The Toronto Star. Toronto. Retrieved from http://www.thestar.com/news/gta/2014/05/30/temporary_torontos_lasting_results _hume.html 
IBA Hamburg. (2013). Metropolis 7: Building the City Anew. JOVIS Verlag GmbH. Retrieved from http://www.ibahamburg.de/fileadmin/Slideshows_post2013/02_Wissen/02_Schriftenreihe/Band 07_Schriftenreihe_Metropole_Stadt-Neu-Bauen.pdf

IBA Hamburg. (2012a). Format IBA. Retrieved February 24/2015, from http://www.ibahamburg.de/en/story/format-iba.html

IBA Hamburg. (2012b). IBA Hamburg: Story of the IBA. Retrieved February15/2015, from http://www.iba-hamburg.de/en/story/iba-hamburg.html

IBA Hamburg. (2012c). IBA Hamburg: Themes of the IBA. Retrieved February 15/2015, from http://www.iba-hamburg.de/en/story/themes-of-the-iba.html

IBA Hamburg. (2012d). IBA Hamburg: Themes of the IBA/Cosmopolis. Retrieved February 15/2015, from http://www.ibahamburg.de/en/nc/projects/cosmopolis.html

Innes, J. E. (1996). Planning through consensus building: A new view of the comprehensive planning ideal. Journal of the American Planning Association, 62(4), 460-472.

Innes, J. E., \& Booher, D. E. (2010). Planning with complexity: An introduction to collaborative rationality for public policy. New York, NY: Routledge Taylor \& Francis Group.

Kato, S., \& Ahern, J. (2007). "Learning by doing": adaptive planning as a strategy to address uncertainty in planning. Journal of Environmental Planning and Management, 51(4), 543-559. http://doi.org/10.1080/09640560802117028

Kiib, H. (2012). Harbourscape Aalborg: Design-Based Methods in Waterfront Development. In H. Smith \& M. S. Garcia Ferrari (Eds.), Waterfront regeneration: experiences in city-building (pp. 115-136). Abingdon, Oxon [England]; New York, NY: Earthscan.

Koolhaas, R. (1998). Whatever Happened to Urbanism. In B. Mau \& R. Koolhaas (Eds.), Small, medium, large, extra-large: Office for Metropolitan Architecture, Rem Koolhaas, and Bruce Mau (2d ed, p. 961). New York, N.Y: Monacelli Press.

Lehtovuori, P., \& Ruoppila, S. (2012). Temporary Uses as a Means of Experimental Urban Planning. Serbian Architectural Journal, 29-54.

Lister, N.-M. E. (1998). A systems approach to biodiversity conservation planning. Environmental Monitoring and Assessment, 49(2/3), 123ñ155.

Lister, N.-M. E. (2010). Insurgent Ecologies: (Re) Claiming Ground in Landscape and Urbanism. In M. Mostafavi \& G. Doherty (Eds.), Projective ecologies (pp. 524ñ535). Lars $M_{s}$ Iler Publishers. 
Lister, N-M. E. (2006). Trashed Space: Reclaiming Urban Junkscape. In J. Knechtel (Ed.), TRASH. Alphabet City (1st ed., pp. 63ñ74). Cambridge, Massachusetts: The MIT Press.

Lister, N.-M. E., \& Kay. (2000). Celebrating Diversity: Adaptive Planning and Biodiversity Conservation. In S. Bocking (Ed.), Biodiversity in Canada: ecology, ideas, and action. Peterborough, Ont. ; Orchard Park, NY: Broadview Press.

Lydon, M., Bartman, D., Woudstra, D., \& Khawarzad, A. (2012). Tactical urbanism: Short-term action, long-term change. ( No. 1). Buffalo, NY: The Street Plans Collaborative.

Marshall, R. (2001). Waterfronts in Post-Industrial Cities. New York, NY: Taylor \& Francis.

Mehrotra, R. (2008). Negotiating the Static and Kinetic Cities. In A. Huyssen (Ed.), Other cities, other worlds: urban imaginaries in a globalizing age. Durham: Duke University Press.

Németh, J., \& Langhorst, J. (2014). Rethinking urban transformation: Temporary uses for vacant land. Cities, 40, 143-150. doi:10.1016/j.cities.2013.04.007

Neuman, L. W. (2011). Social research methods: Qualitative and quantitative approaches, 7/E (7th ed.). University of Wisconsin, Whitewater: Pearson.

Nisenbaum, M. (2008). Temporary Uses and Creativity: A Study on Interim Appropriations of Urban Space in Berlin. Anhalt University of Applied Sciences, Germany. Retrieved from https://www.academia.edu/4611269/Temporary_Uses_and_Creativity_A_study_ on_interim_appropriations_of_urban_spaces_in_Berlim

Oswalt, P., Misselwitz, P., Overmeyer, K. (2007). Patterns of the unplanned: urban catalyst. In F. Haydn \& R. Temel (Eds.), Temporary urban spaces: concepts for the use of city spaces (pp. 271-288). Basel: Birkhäuser.

Oswalt, P., Misselwitz, P., \& Overmeyer, K.. (2013). Urban catalyst: the power of temporary use. Berlin: Dom Pub.

Pagano, C. (2013). DIY urbanism: Property and process in grassroots city building. Marquette Law Review, 97, 101.

Pfeifer, L. (2013). The planner's guide to tactical urbanism. (Unpublished Urban Planning). University of McGill, Montreal, Canada.

Places Victoria. (2015a). Dockland spaces. Retrieved February/05, 2015, from http://www.places.vic.gov.au/precincts-and-development/docklands/building-acommunity/docklands-spaces 
Places Victoria. (2015b). Docklands history. Retrieved January/21, 2015, from http://www.places.vic.gov.au/precincts-anddevelopment/docklands/about/docklands-history

Places Victoria. (2015c). Docklands: Key facts. Retrieved January/21, 2015, from http://www.places.vic.gov.au/precincts-and-development/docklands

Qviström, M., \& Saltzman, Katrina. (2007). Ephemeral Landscapes at the Rural-Urban Fringe. European Landscapes and Lifestyles. The Mediterranean and Beyond, Edições Universitárias Lusófonas, Lisboa, Portugal.

Qviström, M. (2008). A waste of time? On spatial planning and "wastelands" at the city edge of Malmö (Sweden). Urban Forestry \& Urban Greening, 7(3), 157-169. doi:10.1016/j.ufug.2007.03.004

Qviström, M., \& Saltzman, K. (2006). Exploring landscape dynamics at the edge of the city: Spatial plans and everyday places at the inner urban fringe of Malmö, Sweden. Landscape Research, 31(1), 21-41. doi:10.1080/01426390500448534

Reed, C., \& Lister, N.-M. E. (2014). Insurgent Ecologies: (Re) Claiming Ground in Landscape and Urbanism. In Projective ecologies. Harvard Graduate School of Design.

Rittel, H., \& Webber, M. (1973). Dilemmas in a general theory of planning. Policy Sciences, 4, 155-169.

Ronneberger, K. (2006). From Regulation to Moderation. In F. Haydn \& R. Temel (Eds.), Temporary urban spaces: concepts for the use of city spaces. Basel: Birkhäuser.

Shay, A. (2012). The Contemporary International Building Exhibition (IBA): Innovative Regeneration Strategies in Germany. Massachusetts Institute of Technology, Boston, MA.

Smith, H., \& Ferrari, M. S. G. (2012). Experiences in Participation in the Port City of Hamburg. In H. Smith \& M. S. G. Ferrari (Eds.), Waterfront Regeneration: Experiences in City Building (pp. 96-113). New York, NY: Routledge.

Stevens, Q. (2007). The Ludic city: exploring the potential of public spaces. New York, NY: Routledge.

Sola-Morales, I. (2007 [1995]). Terrain Vague. CENTER 14: On Landscape Urbanism. Austin, Texas: Center for Architecture and Design, pp. 108-113.

STEALTH Unlimited. (2003). Amsterdam Noord. Retrieved February/15, 2015, from http://www.stealth.ultd.net/stealth/03_amsterdamnoord.tmp.html

Studio Urban Catalyst. (2003). Urban Catalysts: Strategies for Temporary Uses Potential for Development of Urban Residual Areas in European Metropolises 
(Final Synthesis) (pp. 1-28). Berlin: Urban Catalyst. Retrieved from http://www.templace.com/thinkpool/attach/download/1_UC_finalR_synthesis007b.pdf?object_id=4272\&attachm ent_id=4276

Temel, R. (2006). The Temporary in the City. In F. Haydn \& R. Temel (Eds.), Temporary urban spaces: concepts for the use of city spaces (pp. 55-62). Basel: Birkhäuser.

Tito, E. (2011). Strategies to Animate Toronto's Transitional, Post-Industrial Waterfront. Ryerson University, Toronto, ON.

Turner, T. (1996). GIS, Structuralism, the Birth, the Death and the Life of Planning. In City as landscape: a post-postmodern view of design and planning. London; New York: E \& FN Spon.

Wall, A. (1999). Programming the Urban Surface. In J. Corner (Ed.), Recovering landscape: essays in contemporary landscape architecture (pp. 233-249). New York: Princeton Architectural Press. Retrieved from http://appliedmapping.fiu.edu/readings/wall.pdf

Waterfront Toronto. (2012). Port lands acceleration initiative: Appendix 1 summary of findings. (Summary). Toronto: City of Toronto. 